\title{
The discovery of the Flammer syndrome: a historical and personal perspective
}

\author{
Josef Flammer $^{1} \cdot$ Katarzyna Konieczka $^{1}$
}

Received: 17 February 2017 / Accepted: 27 March 2017 /Published online: 22 May 2017

(C) The Author(s) 2017. This article is an open access publication

\begin{abstract}
This review describes the clinical and basic research that led to the description of Flammer syndrome. It is narrated from a personal perspective. This research was initiated by the observation of an increased long-term fluctuation of visual fields in a subgroup of glaucoma patients. As these patients had strikingly cold hands, peripheral blood flow was tested with a capillary microscopy, and vasospastic syndrome (VS) was diagnosed. Further studies on these patients revealed frequently weakened autoregulation of ocular blood flow and increased flow resistivity in retroocular vessels. Their retinal vessels were more rigid and irregular and responded less to flickering light. Holistic investigation demonstrated low blood pressure, silent myocardial ischaemia, altered beat-to-beat variation, altered gene expression in the lymphocytes, slightly increased plasma endothelin level and increased systemic oxidative stress. This combination of signs and symptoms was better described by the term primary vascular dysregulation (PVD) than by VS. Subsequent studies showed additional symptoms frequently related to PVD, such as low body mass index, cold extremities combined with slightly increased core temperature, prolonged sleep onset time, reduced feelings of thirst, increased sensitivity to smell and also for certain drugs and increased retinal venous pressure. To better characterise this entire syndrome, the term Flammer syndrome (FS) was introduced. Most subjects with FS were healthy. Nevertheless, FS seemed to increase the risk for certain eye diseases, particularly in younger patients. This included normaltension glaucoma, anterior ischaemic optic neuropathy, retinal
\end{abstract}

Katarzyna Konieczka

katarzyna.konieczka@usb.ch

1 Department of Ophthalmology, University of Basel, Mittlere Strasse 91, CH-4031 Basel, Switzerland vein occlusions, Susac syndrome and central serous chorioretinopathy. Hereditary diseases, such as Leber's optic neuropathy or retinitis pigmentosa, were also associated with FS, and FS symptoms and sings occurred more frequent in patients with multiple sclerosis or with acute hearing loss. Further research should lead to a more concise definition of FS, a precise diagnosis and tools for recognizing people at risk for associated diseases. This may ultimately lead to more efficient and more personalised treatment.

Keywords Flammer syndrome · Primary vascular dysregulation · Vasospasm · Glaucoma $\cdot$ Retinitis pigmentosa $\cdot$ Multiple sclerosis $\cdot$ Prediction of health problems

\section{Introduction}

Flammer syndrome (FS) [1] describes the phenotype of people with a predisposition for an altered reaction of the blood vessels to stimuli like cold, emotional stress or hypoxia. Whilst FS has clinical implications in many different medical fields, it emerged originally from ophthalmology, particularly from glaucoma research. Over a span of 40 years, we studied, together with our colleagues, the interrelationship of numerous symptoms and signs and their reference to diseases. This finally led to the description of the FS. This review describes the many steps and milestones of the discovery. With growing knowledge, the terminology changed from vasospasm over vasospastic syndrome (VS) to primary vascular dysregulation (PVD) and finally to FS. The syndrome itself has already been comprehensively described [1-3] and is therefore not the principal content here. The focus of the present review is rather on the history of the discovery and particularly on our own personal experience and contribution during this evolution. 


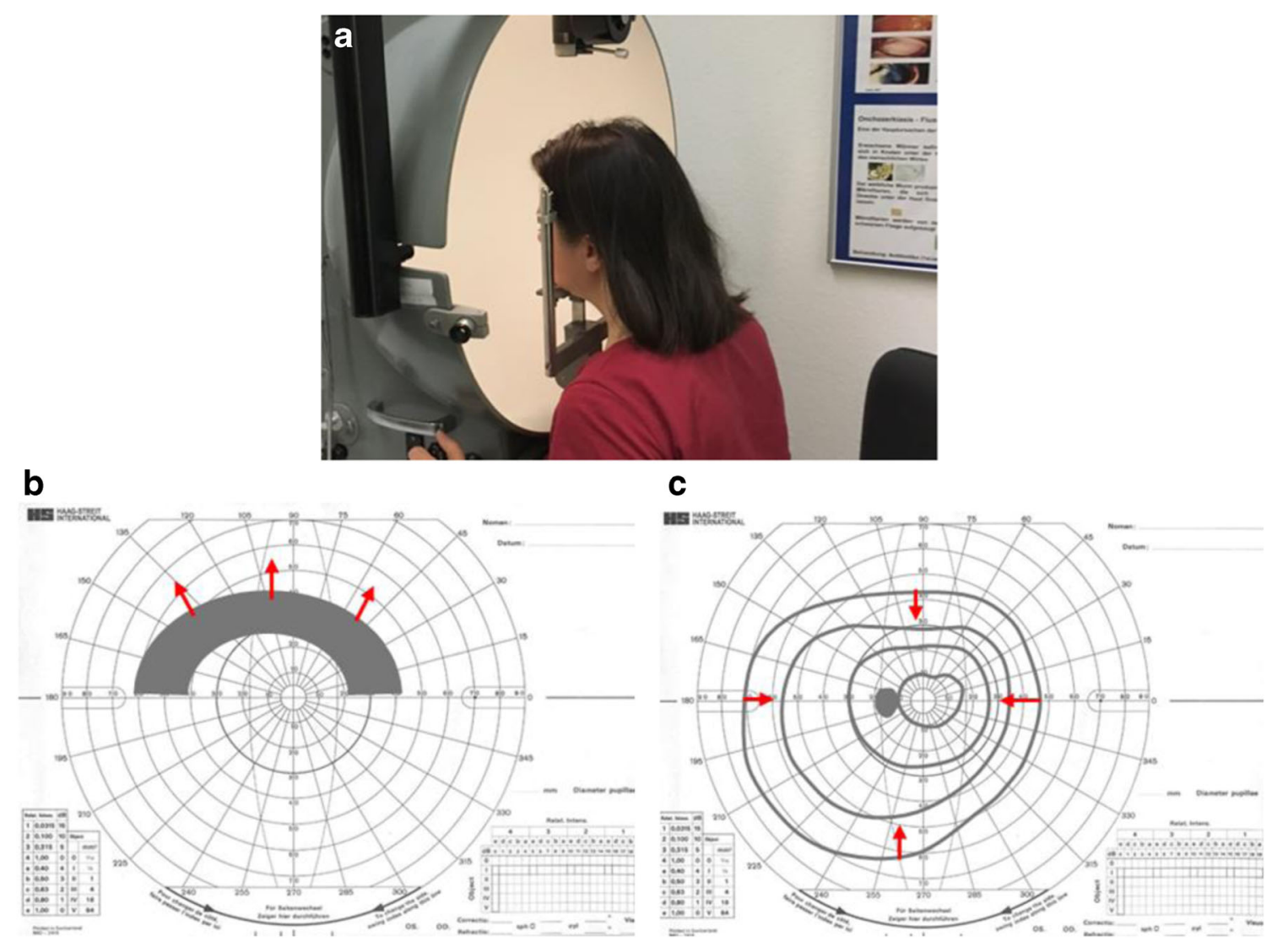

Fig. 1 Long-term follow-up of glaucoma patients with Goldmann perimetry (a) revealed that both the increase of scotomas (b) and the diffuse reduction (c) of the differential light sensitivity were highly related to IOP fluctuations

\section{Visual field testing and ocular blood flow}

Interestingly, the very first roots of FS originated from research in perimetry in the early 80 s when quantification of ocular blood flow (OBF) was difficult to obtain. To explain this, we must first highlight some steps in the development of perimetry. One of the authors (JF) was trained at the university of Bern, where Hans Goldmann had developed the Goldmann perimetry [4] (Fig. 1a) and Franz Fankhauser had developed the first automated perimeter [5] (Fig. 2a), the Octopus [6]. A study with Goldmann perimetry demonstrated that the fluctuation of intraocular pressure (IOP) from day to day was at least as important for progression of the glaucomatous optic neuropathy $(\mathrm{GON})$ as the average IOP $[7,8]$ (Fig. 1b,c). We were initially puzzled by this observation and could only explain this finding many years later by OBF instability and oxidative stress [9-11]. After switching to automated perimetry [12], we realised that the visual field defects, particularly the ones from glaucoma, were both more variable and less stable than expected. Bearing this variability in mind, we developed an Octopus program with integrated statistical methods evaluating the visual fields [13]. This research tool served later as a basis for the development of the Octopus program G1 designed for clinical application [14-16]. We established normal values, accounting for age [17] and topography [18], introduced visual field indices to quantify visual field defects [16, 19, 20], compared the index 'mean defect' with the 'mean deviation' that was introduced later [21] and found some information profit by retests [22], but not by probability weighting $[23,24]$. We separated diffuse from local damage with the cumulative defect curve [25], called the Bebie curve [26], and compared it with other methods to quantify diffuse damage [27]. We also studied learning and fatigue effects [28, 29], the correlation between quantitative perimetry and colour vision scores [30], spatial contrast sensitivity [31] and the optic nerve head morphology [32]. After the introduction of the opacity lens meter [33-37], we studied the influence of cataract density on the visual fields [38-40]. We observed visual field reversibility, e.g. improvement in visual performance after radiation of optic neuropathy that resulted from Graves' disease [41]. We also tested a semi-automated pupillometry on the Octopus [42] and analysed the sources of error in automated static perimetry $[43,44]$ and the diagnostic role of the peripheral visual field [45]. Our main interest focussed, however, on the short- and long-term fluctuations of the visual fields [46-49]. We realised that some patients had extensive large long-term fluctuation of the diffuse but much less of the local component of the defects [50,51], as it can 

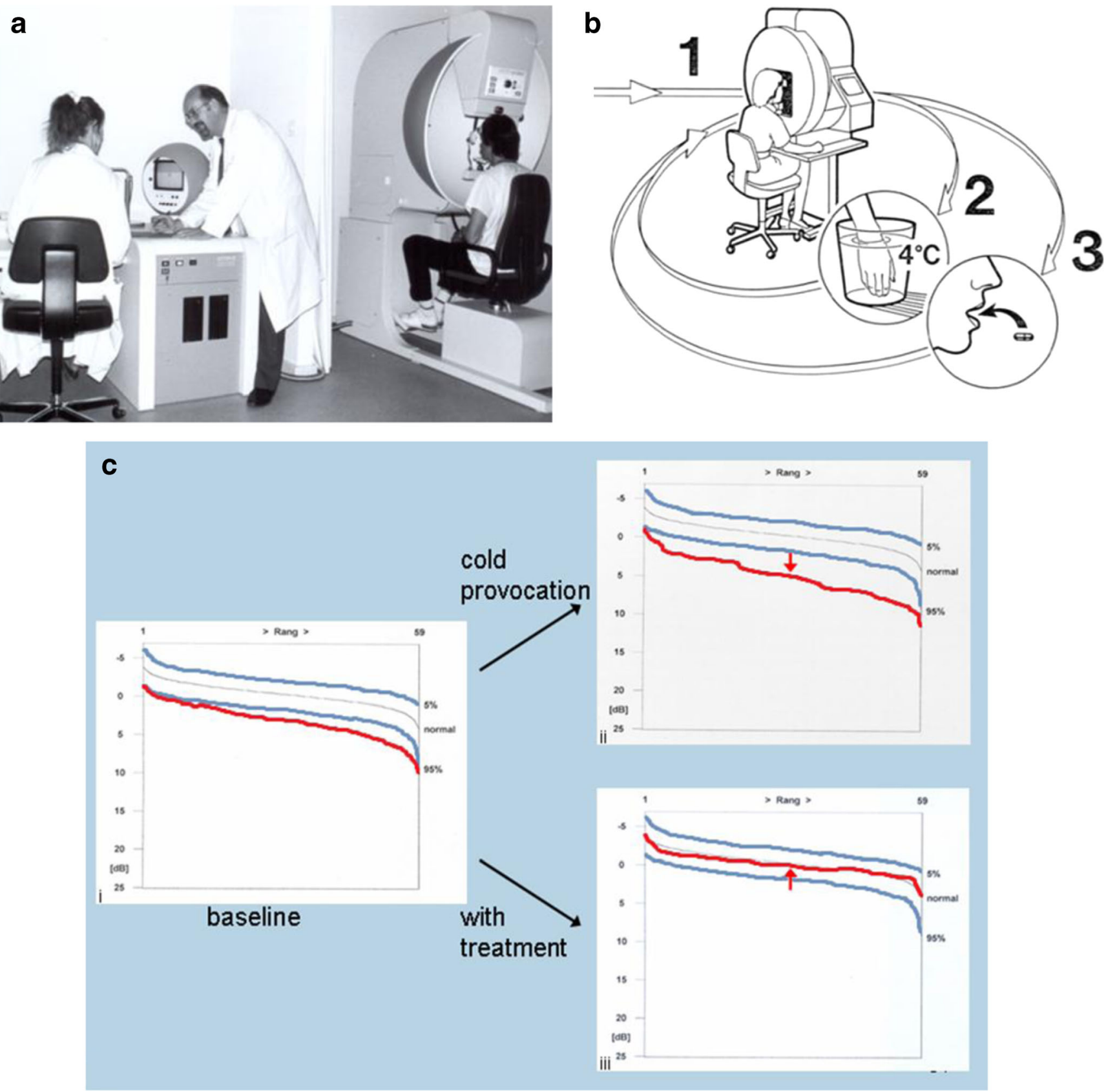

Fig. 2 Perimetry. (a) Octopus instrument of the first generation. (b) The tests were done with the help of the program G1, and the results were presented with the Bebie curve (c). Patients with vasospastic syndrome had slight diffuse depressions of the light sensitivity at baseline; these depressions reversibly increased after cold provocation (c) and were reversed after treatment with acetazolamide or low dose of a calcium channel blocker (modified after ref. [205])

patients (responders) (Fig. 2b,c). These changes occurred unrelated to IOP [57]. This led to the hypothesis that the long-term fluctuation of visual function could be, at least partly, a consequence of fluctuating OBF [58-61], a concept which was harshly attacked by established scientists in the field. This hypothesis was later supported by the observation that vasodilation by breathing $\mathrm{CO}_{2}$ [62] or treatment with calcium channel blockers (CCBs) [55, 63] also improved the visual improved visual sensitivity [56] in a subgroup of 

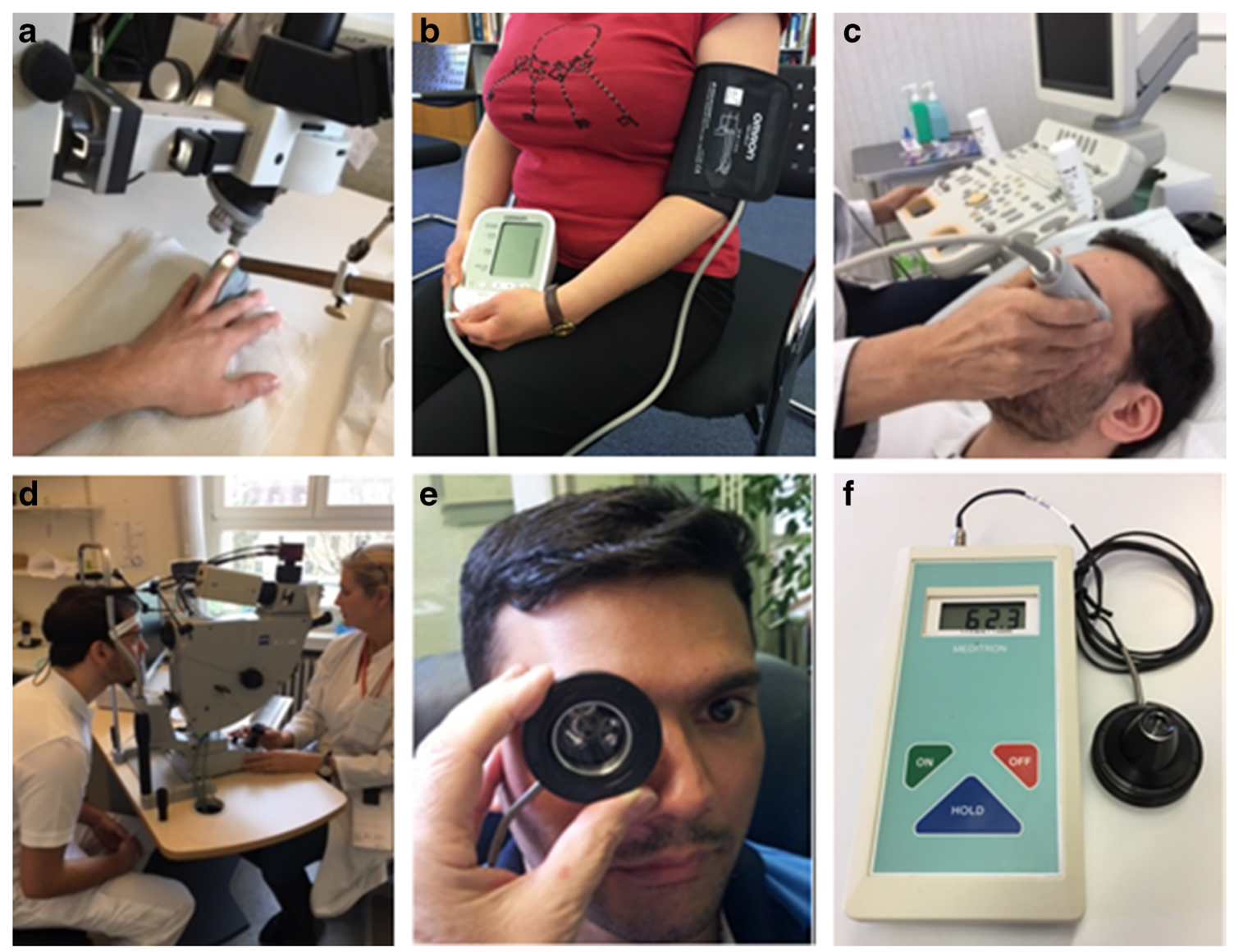

Fig. 3 Quantification of aspects of ocular blood flow. With time, new methods were introduced step by step and contributed to the understanding of the Flammer syndrome. Capillary microscopy with cold provocation (a), 24-h blood pressure monitoring (b), colour

Doppler imaging (CDI) of the retroocular vessels (c), static and dynamic analyses of the diameter of retinal arteries and veins at baseline and after flicker light stimulation (d) and quantification of retinal venous pressure $(\mathbf{e}, \mathbf{f})$

fields in these types of patients. In other words, the patients with large long-term fluctuation were also the responders to cold and to acetazolamide and CCBs. But why did some patients respond and others did not? [64]. What were the characteristics of the responders? A more detailed consideration of individual cases provided some clues.

\section{Glaucoma patients with cold hands}

In the early 80 s, a 45 -year-old, slim, intellectual and sportive lady with progressive normal-tension glaucoma (NTG) came to see JF for a second opinion. She reported that her internist attested her to be of excellent health. However, her hands were strikingly cold, and, keeping the perimetry studies in mind, we asked whether this may somehow be related to her NTG. Although she emphasised that this was totally normal for her and that her mother also had cold hands, she agreed to be tested by nailfold capillaroscopy. The cold provocation led to a prolonged flow cessation in the nailfold capillaries and the angiologist diagnosed VS [65] (Fig. 3a).

\section{Glaucoma patients with VS}

We knew now that this patient had two conditions: VS and an NTG. What we did not know was whether these two conditions were related. When treating the VS with a $\mathrm{CCB}$, not only did her hands became notably warmer but the visual fields also improved. After observing additional similar cases, we postulated that VS could be a risk factor for NTG [66]. At that time, our hypothesis was considered absurd by most experts, but the findings impressed Dr. S.M. Drance, the former teacher of JF. He visited our lab and subsequently confirmed our observation using another method, namely a laser Doppler flowmeter to quantify BF in the finger [67]. Our own studies with capillaroscopy reconfirmed the longer flow cessation after cooling and reduced blood flow velocity [68] in a subgroup of NTG patients. The induced visual field changes correlated with the blood flow changes in the finger [69], reaffirming that the outcome of perimetry may depend on OBF. Years later, we were able to confirm a relationship between OBF and finger blood flow [70]. However, this correlation existed only 
in the subgroup of patients with VS, not in subjects without VS.

Taken together, subjects with VS responded to provocation and treatment with both finger blood flow and the visual fields. These responders also seemed to be at greater risk for NTG and potentially for other eye diseases $[58,71]$. But one problem at that time was this: we could only postulate the involvement of ocular blood flow (OBF) in VS, and we were not able to measure it directly [72]. Our theory therefore remained vulnerable.

\section{Systemic hypotension, a component of the VS}

Whilst we know today that arterial hypertension increases the risk for ocular hypertension and thereby also the probability for high-tension glaucoma (HTG), arterial hypotension increases the risk for GON at a given IOP. The question of the role of systemic blood pressure (BP) in glaucoma was a matter of hot debate at that time. Some authors claimed hypertension and others hypotension to be related to glaucoma, yet others claimed that BP played no role at all. We monitored 24-h blood pressure [73] and found many glaucoma patients with low BP, particularly at night (Fig. 3b). In fact, it turned out that both HTG patients with progression despite well-controlled IOP and NTG patients had significantly lower BP [74]. The lower the BP was, the longer the flow cessation in the nailfold capillaries after cold provocation was [75]. The endothelin sensitivity correlated positively with the apolipoprotein B concentrations [76] but inversely with BP [77]. Although VS and arterial hypotension independently increased the risk for GON [78], the prevalence of these two risk factors was clearly related. In other words, arterial hypotension was a frequent sign of VS. If BP was too low, we asked patients to increase their salt intake and in extreme cases treated them with fludrocortisone $[79,80]$.

\section{Increased blood flow resistivity, an additional component of VS}

In the early 1990s, colour Doppler imaging (CDI) reached a resolution that made it possible to measure blood flow or at least flow velocity in retroocular vessels (Fig. 3c). We established normal values [81], frequency distribution [82] and reproducibility [83]. We then observed an increased flow resistivity, not related to IOP, in a subgroup of glaucoma patients [84]. Although this increase in resistivity was not specific for VS [85], it could not be explained by hypercholesterolemia [86] or smoking [87], indicating that arteriosclerosis was not likely the cause. However, the resistivity was inversely related to BP $[75,88]$ and patients with nocturnal dips [88] and with VS [89] had higher resistivity. Taken together, this was a strong indication that VS also affected the ocular blood flow and that a number of drugs, such as dipyridamole [90], could reduce this flow resistivity.

\section{Regulation of ocular vessels in ex vivo studies}

We also studied the physiology and pharmacology of the eye [91-113]. The involvement of OBF in VS motivated us to study the regulation of $\mathrm{OBF}$ in particular. We isolated retroocular vessels and studied them with the myograph system (Fig. 4a). Using this experimental setup, we described the endotheliumdependent regulation of vascular tone [114, 115], including its heterogeneity [116], the role of nitric oxide and endothelin (ET) [117] and the refractoriness to the effect of ET [118]. We described the localisation of AT1- [119, 120], melatonin- [121] and melanin-concentrating hormone receptors [91] and characterised the influence of local anaesthetics [122]. Further studies explored the effect of ACE inhibitors and angiotensin receptor antagonists [123], of CCBs [124] at high and low doses [125], dipyridamole [126], potassium-channel blockers [127] and openers [128], magnesium [129], ox-LDL and the ET antagonists BQ 123 [130] and avosentan [131], bimatoprost [132], carteolol [133, 134], PGF2alpha [135] travoprost [136], latanoprost [137, 138], melatonin [139] and adrenomedullin [140]. We also studied the regulation of the vortex vein [101]. Findings with isolated vessels were then also confirmed in a

a

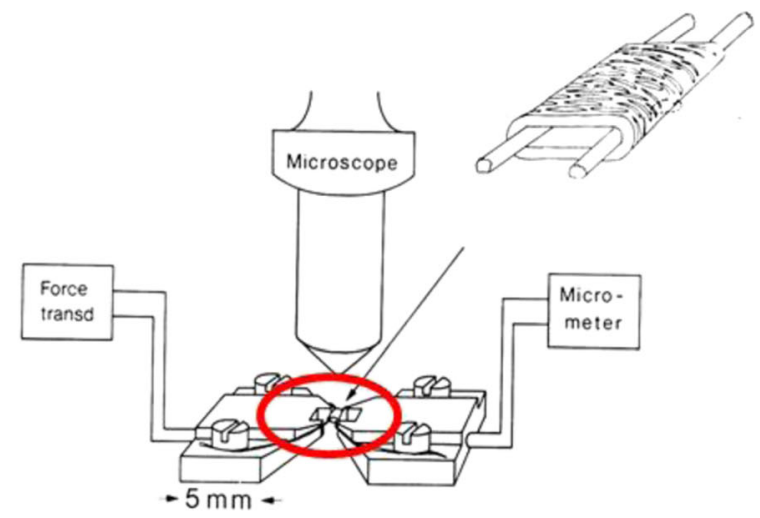

b

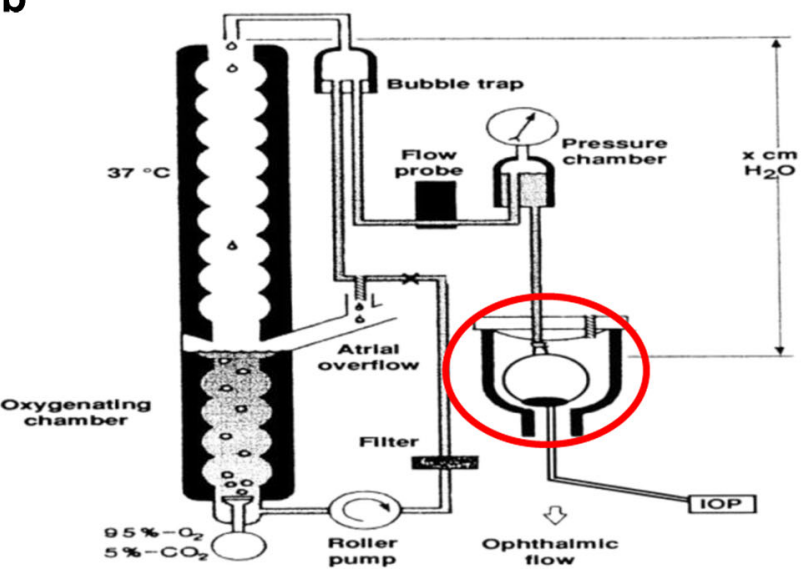

Fig. 4 Physiological and pharmacological ex vivo testing of ocular vessels, with the help of a myograph system (a) and the help of a perfused eye model (b) (modified after ref. [141]) 
perfused eye model [141] (Fig. 4b). Other groups studied the retinal arteries [142] and veins [143].

Taken together, we learned (i) that ocular vessels were highly regulated, particularly by the vascular endothelium cells, and therefore, a dysregulation due to an endotheliopathy was conceivable; (ii) that the regulation was different from one vessel to another and there was even inhomogeneity within the same vessel; and (iii) that many different drugs influenced OBF. On the one hand, this opened the door for new therapeutic strategies, but on the other hand, it made it necessary to ask patients for local and systemic drugs they were using when interpreting OBF [144-150].

\section{BF is influenced by local and systemic factors}

The optic nerve head $(\mathrm{ONH})$ was of special interest in diseases like glaucoma. However, measuring blood flow $(\mathrm{BF})$ in the ONH was difficult $[151,152]$. It was therefore of interest to know whether $\mathrm{BF}$ in different tissues was related. Indeed, $\mathrm{ONH} \mathrm{BF}$ correlated with retrobulbar [153] and finger BF [70]. Low corneal temperature was a risk indicator for glaucoma progression [154], and corneal temperature correlated with BF in the ophthalmic artery [155] and with finger temperature [156]. BF in the ophthalmic artery, in turn, correlated with BF in nailfold capillaries [157]; choroidal BF however (mainly regulated by the autonomic nervous system) was inversely related to finger $\mathrm{BF}$ [158].

As a rule, correlations were always present in subjects with VS but not in others. This indicated that in subjects with VS, local regulation was less efficient, and therefore, systemic factors such as perfusion pressure gained more influence.

\section{The role of gender and body mass index}

In the early 1990s, it was known that obesity was a risk factor for many diseases including an IOP increase. However, our patients with NTG tended to be rather slim $[159,160]$ and were more often female than male [161]. In addition, subjects with low body mass index had lower blood pressure and more often had cold hands [160]. Cold hands or feet occurred at the highest intensity in younger, slimmer women and at lowest intensity in elderly, stouter men [162]. The lower the BP and/or the BMI is, the colder the extremities were [160]. It became clear that low body mass index increases the risk for VS and VS occurs more often in females.

\section{Silent myocardial ischaemia}

We were confronted with a functional vascular problem, measurable in the fingers but obviously also affecting the eye. We therefore asked whether this vascular phenomenon may also affect other organs such as the heart. Episodic asymptomatic 'silent' myocardial ischaemia was revealed by 24-h ECGs in many patients with glaucoma, especially normal-tension glaucoma. These episodes did not occur during exercise but at rest, particularly at night, indicating that they were not due to arteriosclerosis but rather due to a functional vasoconstriction [163-165].

\section{The autonomic nervous system}

Our observations raised the question of whether this vascular dysfunction could be a consequence of an autonomic nervous system dysfunction [166]. Whilst the analysis of the beat-to-beat heart rate variation proved an involvement of the autonomic nervous system [167], the dynamic vessel analysis demonstrated a vascular dysregulation also in the non-innervated retinal vessels $[168,169]$. This indicated that although VS affected the autonomic nervous system, the imbalance of the autonomic nervous system could not be the sole or even the main cause for the vascular dysfunction.

\section{The vascular endothelium cells}

Beside autonomic innervation and circulating vasoactive hormones, the vascular endothelial cells play a crucial role in the local regulation of BF. The human body has about $10^{13}$ capillaries and $10^{19}$ endothelial cells with a total volume that corresponds to the liver. In the past, the vascular endothelium was believed to be just a simple semi-permeable membrane lining the inner part of arteries, veins and lymphatic vessels. Today, we know that endothelial cells interact with immune cells and regulate haemostasis, angiogenesis and, in particular, the vascular tone [170]. They play also a dominant role in the regulation of OBF [171]. In humans, endothelial dysfunction is one of the first clinically detectable alterations in the development of atherosclerosis. Interestingly, however, we found an endothelial dysfunction with the retinal vessel analyser [172] (Fig. 3d) also in nonarteriosclerotic subjects with VS $[2,165,168,173,174]$, including some weakness of the blood-retinal barrier [175]. The cause of this endothelial dysfunction in these healthy and often very sportive subjects with VS was unclear.

\section{Altered expression patterns in blood cells}

At that time, we had no idea about possible molecular mechanisms that governed VS. Under clinical conditions, the cells of interest, e.g. from the eye, were not amenable. Since we had hypothesised some systemic effects at the level of the gene regulation, we analysed gene expression profiles in peripheral leucocytes applying a 'gene hunting' approach and, indeed, found differences in glaucoma patients with VS against controls [176]. The expression profiles were characteristic for adherent leukocytes [177]. Several key pathways have been found to be differently regulated in glaucoma patients with VS including 
altered stress response, multi-drug resistance and energy metabolism; shifted regulation of transcription, apoptosis and adhesion; deficits in DNA-repair efficacy; blood-brain barrier breakdown; extensive tissue remodelling, etc. [178]. Therein, the enhanced $20 \mathrm{~S}$ proteasome alpha-subunit levels pointed towards increased oxidative stress [179]. Upregulated MMP-9 and MT1-MMP gene expressions were compatible with the observed partial blood-retinal barrier breakdown [175, 180]. Subjects with VS exhibited differential expression of ABC-transport proteins [181], potentially explaining the altered drug sensitivity [1], and an enhanced expression of ABC 1 transporter was considered to be potentially involved in the vascular dysregulation [182]. The protein expression of AP- $2 \beta$ was increased in both NTG and primary open-angle glaucoma, indicating that this may be related to glaucoma but not to VS [183]. The gene expression profiles were different amongst healthy subjects, patients with high-tension, PEX and normal-tension glaucoma [184]. Interestingly, the expression profiles of NTG patients were very similar to those of healthy subjects with VS $[185,186]$. This reinforced the idea of a close relationship between VS and NTG. No differences were found in the genotype frequencies of polymorphisms of the nitric oxide pathway between Caucasian normal and high-tension glaucoma patients [187].

\section{From vasospasm to vascular dysregulation}

Vasospasms have been known in medicine for decades [188] and have also been linked to eye diseases [55, 189], particularly to glaucoma $[59,190]$. But the clinical condition we were dealing with in our NTG patients could not be explained by isolated spasms as we knew them, for instance in the retinas of patients with retinal migraine [191]. We were faced with a more global phenomenon, which at that time was described by the term VS [65, 71, 192]. However, this term still suggested mainly abnormal constrictions of arteries. We observed a more general dysregulation, involving arteries, capillaries and veins, including a disturbed autoregulation of OBF [173, 193], abnormal response to hand-grip stimulation [194] or blood gas perturbations [195] and altered responses of both visual fields [196, 197] and ET-1 plasma levels [198] to a change of body position from supine to upright [199]. We therefore considered the term vascular dysregulation more appropriate, particularly in the context of glaucoma $[9,190$, 200-203].

It also became clear that we needed to separate primary from secondary dysregulation [9, 71, 190, 200, 201, 203]. It turned out that a number of diseases induce secondary vascular dysregulation which can be more local, e.g. due to arteriosclerotic plaques, and more systemic, e.g. due to a high level of ET in the circulating blood.

\section{Secondary vascular dysregulation}

Secondary vascular dysregulations are neither essential risk factors for normal-tension glaucoma nor part of the FS. But for the sake of completeness, let us briefly discuss them, in particular the role of endothelin (ET). Under physiological conditions ET, a potent vasoconstrictor produced by vascular endothelial cells is mainly released abluminally to regulate local vascular tone [204]. A smaller amount is released intraluminally, contributing to an ET level in the circulating blood [205]. Under pathological conditions (such as inflammations and hypoxia), other cells also produce ET and thereby increase ET levels in the blood. As long as the blood-brain and blood-retina barriers are intact, this has little influence on retinal or brain circulation [206]. However, ET reduces the circulation in the choroid due to fenestrated capillaries [207] and in the optic nerve head due to diffusion from the choroid into the ONH $[2,165,175]$ (Fig. 5a). We found increased ET levels in giant cell arteritis [208], rheumatoid arthritis [209], fibromyalgia syndrome [210], multiple sclerosis [211, 212], optic neuritis [213], retinal vein occlusions [214], retinitis pigmentosa [215], Susac syndrome [216] and in patients with cystic macula oedema that responded poorly to anti-VEGF therapy [217]. The border between primary and secondary vascular dysregulation is sometimes vague, which we will discuss by way of the example of multiple sclerosis (MS) further below.

\section{The primary vascular dysregulation}

Vascular dysregulation refers to the regulation of blood flow that is not adapted to the needs of the respective tissue. We determined a vascular dysregulation to be 'primary' if no causing disease but a certain genetic predisposition was present $[9,190,201]$. For a detailed description of primary vascular dysregulation (PVD), we refer the reader to a recent comprehensive review [2]. Virtually, all organs, particularly the eye, can be involved. Retinal vessels were stiffer both in patients with glaucoma [218] and in those with PVD [219] and were more irregular [220] in PVD subjects. The vascular response to flicker light was reduced both in patients with glaucoma [174] and with PVD [168, 169] (Fig. 3d). The autoregulation capacity in PVD subjects [173] was reduced, whilst retinal venous pressure was often increased [221]. Subjects with PVD had increased risk for normaltension glaucoma [59], optic nerve compartment syndrome [222], central serous choroidopathy [223], Susac syndrome [216], retinal artery and vein occlusions [224] and anterior ischaemic neuropathy without atherosclerosis [214]. Further characteristics were their weaker blood-brain and blood-retinal barriers $[175,206]$ and the higher prevalence of optic disc haemorrhages [206] and activated astrocytes [225]. 
a

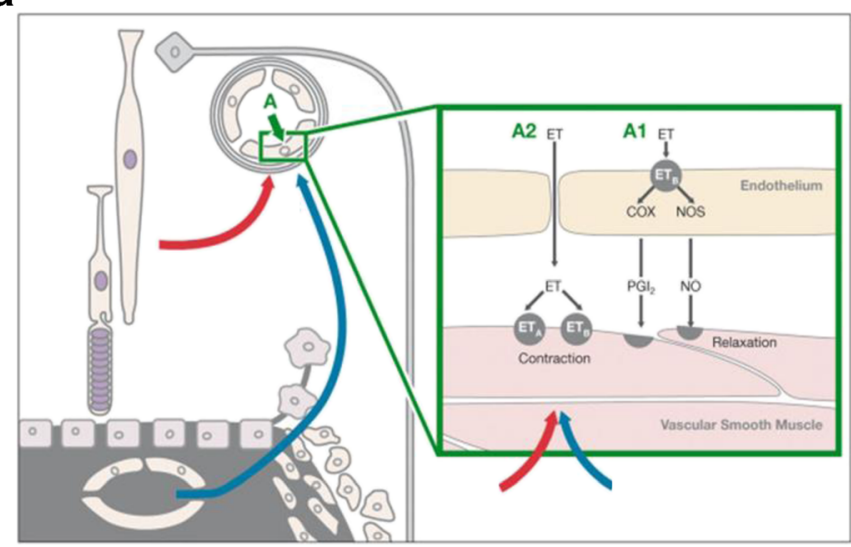

b

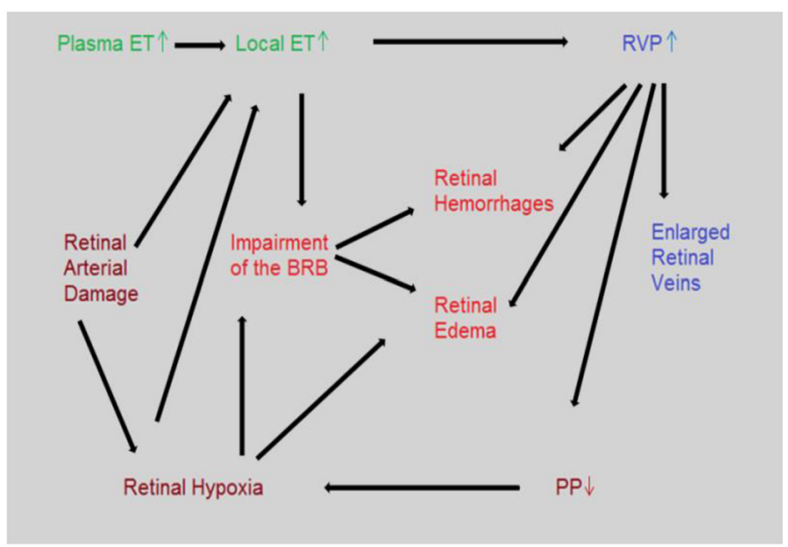

C
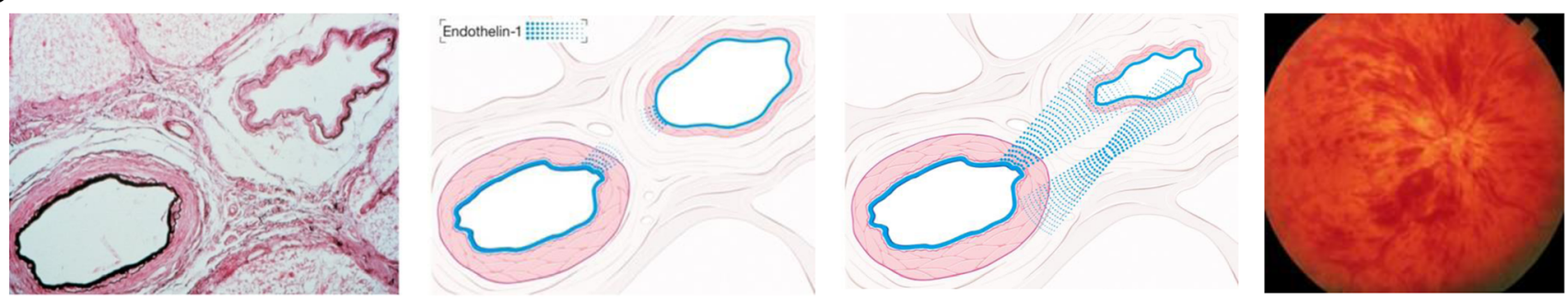

d
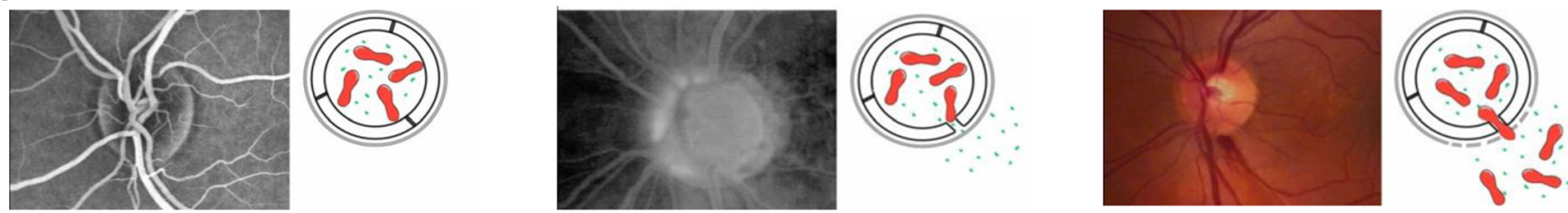

Fig. 5 The blood-retina barrier prevents a direct access of circulating molecules (such as a vasoconstrictor endothelin (ET)) to the smooth muscle cells of the retinal vessels. These molecules can however diffuse form the choroid into the optic nerve head $(\mathrm{ONH})$, bypassing this barrier (blue arrow in a) (modified after ref. [204]). ET can also be produced by

the neighbouring hypoxic tissue (red arrow in a) or diffuse from diseased arteries to adjacent veins (c) (modified after ref. [259]). These can potentially increase retinal venous pressure and finally contribute to the pathogenesis of retinal vein occlusion (b) (modified after ref. [221]) but also to the pathogenesis of haemorrhages (d) (modified after ref. [175])

\section{Vascular dysregulation in multiple sclerosis}

Amongst the subjects with PVD, we relatively frequently saw cases diagnosed by their neurologists as suspected MS, confirmed MS and sometimes Susac syndrome. A certain but not yet well-understood interrelationship was obvious. On the one hand, PVD could imitate some symptoms and signs of MS-like paraesthaesia, temporal pallor of the $\mathrm{ONH}$, visual field defects and prolonged latency in VEP or pathological MRI. In contrast to MS, however, we did not see oligoclonal bands in the cerebrospinal fluid of PVD subjects. On the other hand, MS (like other autoimmune diseases) could lead to a secondary vascular dysregulation [71] with increased ET plasma levels [211] and reduced OBF [212]. MS patients without a history of retrobulbar neuritis had subclinical visual field defects [226], narrower retinal arterioles and wider retinal venules [227], increased rigidity of these retinal vessels [228] and thinning of the macula [229]. During optic neuritis, we observed a

transient raise of the ET plasma levels, a reduction of ocular blood flow [213], an improvement of visual function after intake of red wine [230] and a distension of the optic nerve sheaths [231]. A controlled study confirmed the presence of FS symptoms in MS patients [232]. Taken together, we postulated that on the one hand, PVD may not only imitate some MS symptoms but also increase the risk for MS, probably by subclinical cerebral microinfarctions promoting autoimmunity. On the other hand, MS-induced inflammations may evoke secondary vascular dysregulations contributing to chronic progression in a later stage [2].

\section{The patients are our teachers: clinical symptoms of PVD}

Given the complexity of these different parameters and their interactions, one may wonder how we found different signs and symptoms related to PVD. Patients often reported 
elements seemingly unrelated to their diseases. If other patients reported similar symptoms, we became suspicious and studied a potential relationship with PVD.

\section{Reduced feeling of thirst}

As many of our patients suffered from low BP, we asked them whether they drank enough. Most patients said yes, but not because they were thirsty, only because they knew they had to drink. A controlled study confirmed that subjects with PVD drank more or less enough but indeed had significantly less desire to drink [233]. We assumed that ET (which was slightly increased in subjects with PVD) suppressed the feeling of thirst via upregulation of PGE2 [2]. Correspondingly, the feeling of thirst was also reduced in other diseases with increased ET plasma levels such as in MS [232], retinitis pigmentosa [215, 234, 235], giant cell arteritis [208], polyarthritis [209] or fibromyalgia [210].

\section{Increased smell perception}

Olfactory dysfunction is one of the first symptoms in neurodegenerative diseases. Therefore, we asked our glaucoma patients about smell perception. Whilst patients with glaucoma and with MS had reduced olfactory function [232, 236], subjects with PVD identified odours significantly better than those without PVD [237].

\section{Prolonged sleep onset time}

Visually handicapped subjects, such as patients with advanced glaucoma, potentially lose their circadian rhythms due to disturbed melatonin cycles. Melatonin mediates the arousal system and is also involved in thermoregulation by fine-tuning vascular tone in selective vascular beds [238]. To fall asleep, we need to warm up our feet to a certain temperature [238]. Our patients with PVD often reported long sleep onset time that could be shortened by wearing socks or taking a warm bath. A controlled study confirmed the prolonged sleep onset time [239] and its relation to cold extremities [240].

\section{Phase delay}

Our patients often reported being 'evening persons'. Subjects with PVD exhibited a normal phase relationship between skin temperature and sleep-wake rhythms [241] but a phase delay of the endogenous circadian system with respect to their habitual sleep-wake cycle [242].

\section{Cold feet}

When shaking hands with NTG patients, cold hands were often a striking symptom (Fig. 6a). When asked, these subjects also often indicated having cold feet. When objectively measured, the most constant sign for PVD was an increased temperature difference between lower and higher leg over the entire day but disappearing during sleep. These differences in distal to proximal skin temperatures were independent of the menstrual cycle [243].

\section{Increased sensitivity}

Patients often told us stories that we could sooner or later relate to PVD. One patient felt an earthquake when nobody else around her could feel it. It turned out that she was actually right. Indeed, sensation to vibration was increased [2]. Another patient told us that she became unconscious during a balloon ride. PVD subjects have an increased sensitivity to hypoxia, as it occurs due to low air pressure at high altitudes [244]. One NTG patient experienced a sudden onset of a scotoma during skiing, and three patients became unconscious when jumping into the cold water of the sea. An increased response to cold is typical for PVD. Pain sensation was often reported to be increased [59], and we assumed that an increased level of ET [233, 245] reduced the peripheral pain threshold. Many patients reported increased sensitivity to certain drugs, which could be explained, at least in part, by the differential expression of ATP transport proteins [181]. Sensitivity to psychological stress also seemed high but has not yet been studied scientifically.

\section{Intensified physical exercise}

PVD subjects did physical exercise more often and more vigorous than the average population, and they also seemed to enjoy it more. They particularly often indicated doing running and cycling. Very rarely, however, vasospasms were induced by exercise.

\section{Ocular manifestations of PVD}

Most subjects with PVD were healthy and also free of eye diseases. Nevertheless, they had an altered regulation of OBF [2]. Some PVD subjects developed visible alterations or even diseases, which will now be discussed:

\section{Activated astrocytes in the retina}

In the early 1990s, we observed morphological alterations resembling fine epiretinal gliosis (Fig. 6c). Unlike the real epiretinal gliosis, however, the gliosis-like alterations occurred mainly in the midperiphery of the retina, spared the macula area and never pulled on the retina [246]. Examination with a laser-scanning ophthalmoscope confirmed sharply bordered, patchy retinal alterations in the 
a
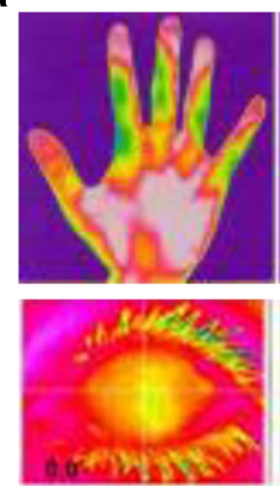

b

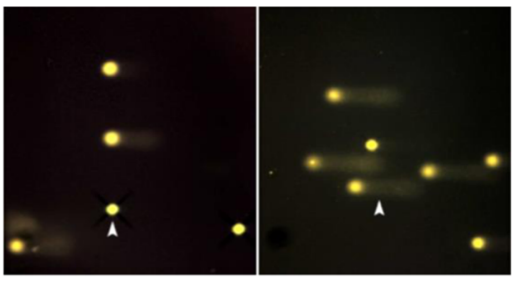

C

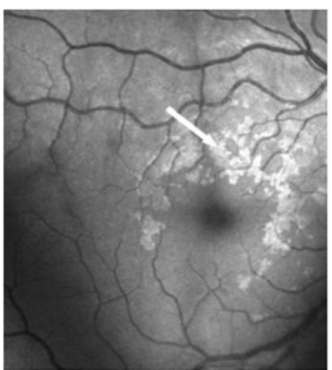

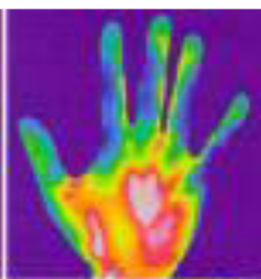

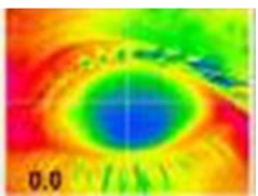

Autoregulation disturbed

\section{Development of GON}

(Concept of J. Flammer)

\section{Flammer Syndrome low / instable}

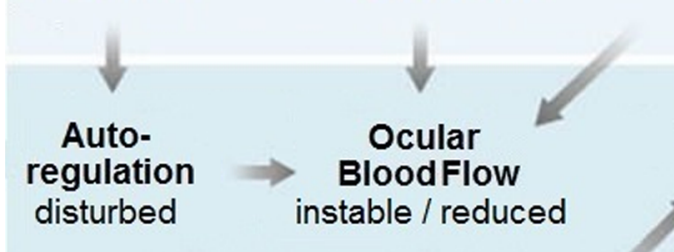

\section{Astrocytes activatied}

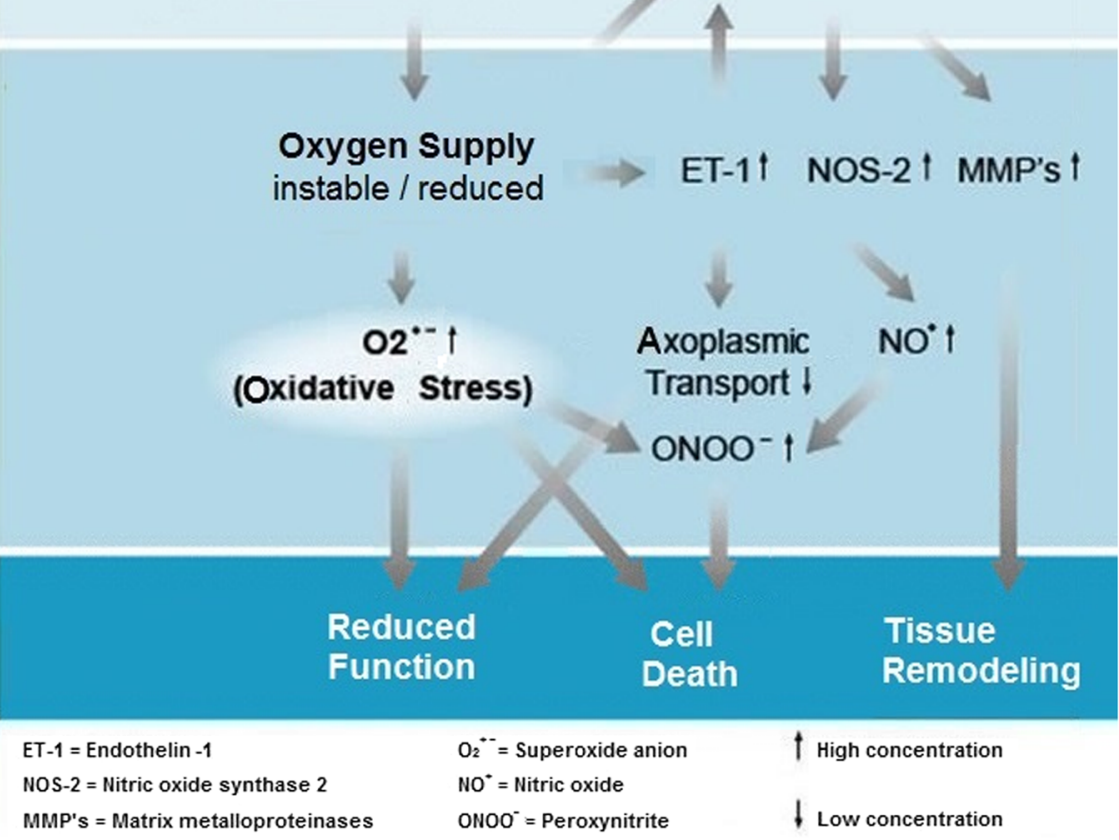

Fig. 6 The pathogenetic concept of glaucomatous optic neuropathy $(\mathrm{GON})$. Beside an increased intraocular pressure, a disturbed vascular dysregulation as demonstrated with thermography of the hands and the eyes (a) plays an important role (modified after ref. [205]) This leads to an increased oxidative stress as demonstrated with the comet analysis (b) (modified after [288]). The activated astrocytes change their gene expression, but also morphology. This increases the backscatter as demonstrated in red-free photos (c, left) (modified after ref. [225]). This also reduces the transport of oxygen from the blood vessels to the neurons (c, right). The oxygen tension in the axons decreases and in the retinal veins increases. The entire concept is summarised in $\mathbf{d}$ (modified after ref. [250]) superficial layers, also called activated retinal astrocytes and Müller cells (ARAM) [225]. Based on occurrence, distribution and phenomenology, we postulated that these patchy alterations were due to an increased backscatter of light by activated astrocytes [247, 248] This phenomenon occurred much more often in subjects with PVD [225], indicating that the blood flow disturbance may have triggered glial cell activation. Examinations with OCT suggested that ARAM may mask retinal nerve fibre loss [249]. Activated astrocytes loose partly their contact with blood vessels and neural axons, preventing normal oxygen transport (Fig. 6c). The consequences are on the one hand a hypoxia in neural cells and on the other hand increased venous oxygen saturation [250].

\section{Central serous chorioretinopathy}

Patients with central serous chorioretinopathy demonstrated a localised delay in arterial filling in the area of the damaged retinal pigment epithelium, frequently associated with dilated capillaries and draining venules. In some patients, localised choroidal ischaemia could be observed in additional areas throughout the central fundus in both diseased eyes and normal fellow eyes [223, 251]. Clinical experience indicated that PVD may be one of the risk factors, probably by causing local hypoxia and oxidative stress. Whilst PVD was more frequent in females, central serous chorioretinopathy occurred more often in young men. A minimal level of testosterone seemed to be a requirement [252]. 


\section{Barrier dysfunction and optic disc haemorrhages}

The optic nerve head, although part of the central nervous system, lacks classical blood-brain barrier properties. In glaucoma, the blood-brain barrier in and around the optic nerve head was even weaker $[175,253]$. We postulated that optic disc splinter haemorrhages were manifestations of a barrier breakdown. If ET opened the barrier on the level of endothelial cells and at the same time MMP-9 weakened the basal membrane, even erythrocytes could escape, leading to the clinical picture of splinter haemorrhages (Fig. 5d). We observed this not only in patients with glaucoma but also in non-glaucomatous subjects with PVD [206].

\section{Anterior ischaemic optic neuropathy}

The $\mathrm{ONH}$ is a very vulnerable tissue. It contains nonmyelinated nerve fibres consuming more energy than myelinated fibres. In addition, they are exposed to light and to mechanical forces. The ONH lacks a normal blood-brain barrier, providing circulating molecules such as ET or angiotensin direct access to the smooth muscle cells. Whilst the arterial supply stems from the ciliary circulation, the veins empty into the retinal veins, causing the ONH perfusion dependent on retinal venous pressure. The intraocular vessels do not become arteriosclerotic, but the retroocular vessels are heavily involved in arteriosclerosis, probably due to extensive movement by the rotation of the eye. Correspondingly, arteriosclerosis is a strong risk factor for anterior ischaemic optic neuropathy (AION). Nevertheless, AION also occurred in non-arteriosclerotic patients in the presence of PVD. In this case, it occurred nearly always after emotional stress [254, 255]. We observe AION even in children [256] and as a perioperative complication [257, 258].

\section{Retinal vein occlusion}

The classical theory was that retinal vein occlusion (RVO) was a consequence of a thrombus in the retinal vein. In the mid-1990s, we saw seven patients with RVO at the age of $<45$ years. Extensive evaluations revealed no pathology except increased responses to coldness in the nailfold capillaries and a history of emotional stress [224]. We hypothesised that dysregulation of retinal veins may have played an essential role in the genesis of their RVO, an assumption later supported by the observation of increased ET plasma levels in such patients [214]. Some years later, we reviewed our knowledge of RVO at that time and came to the conclusion that dysregulations of retinal veins must be one of the principal factors in the pathogenesis of RVO [2, 221, 259] (Fig. 5b).

\section{Cilioretinal arterial occlusion}

We observed a cilioretinal arterial occlusion in a 17-year-old young man without any vascular risk factors except FS with an increased retinal venous pressure. With a treatment of a very low dose of nifedipine, the patient remained without relapse [260].

\section{Choroidal infarction}

Occlusions of small end arteries in the choroid with corresponding point-shaped infarctions of the pigment epithelium can frequently be observed in PVD subjects. Extended choroidal infarctions occur less frequent but have also been described [261].

\section{Retinitis pigmentosa}

Retinitis pigmentosa (RP) refers to a group of degenerative eye diseases with a genetic background. Here, OBF seems to influence manifestation and progress. We observed reduced ocular pulse amplitude in RP patients [262]. A review of the literature revealed evidence of OBF reduction in all stages of RP [235], but it remained open whether this was secondary to the retinal degeneration. The retinal-vessel oxygen saturation correlated with structural alterations [263]. Increased ET plasma level [215] pointed towards a primary vascular component. This assumption was then strongly supported by the observation of a significant association of RP with FS [234].

\section{Optic nerve compartment syndrome}

In optic nerve compartment syndrome (ONCS), there is proven segregation of CSF between the intracranial subarachnoid space and the subarachnoid space surrounding the optic nerve. This leads to differences of fluid composition, reduced CSF exchange and an extension of the optic nerve sheath diameter due to increased pressure [222, 264-274]. We observed that ONCS was often related to PVD [2] and that treatment of FS with a low dose of CCBs also reduced ONCS [275].

\section{Leber's hereditary optic neuropathy}

Leber's hereditary optic neuropathy (LHON) is a mitochondrial inherited retinal degeneration affecting predominantly young adult males. It leads to a subacute drop in vision with central visual field defects, starting in one eye and involving the other eye some weeks later. Most of the patients we saw also suffered from PVD [2]. LOHN and PVD may act synergistically. PVD increases the oxidative stress and therefore affects the mitochondrial function, with a particular impact in 
patients with already weakened mitochondria due to mutations of the mitochondrial DNA [276].

\section{Decreased vessel density}

Vascular regulation is very complex and includes also alternating transient closing of microvessels. An increased ratio of temporally non-perfused vessels can also be a manifestation of a vascular dysregulation giving the impression of a reduced vessel density when blood flow is imaged, e.g. by optical coherence tomography angiography.

\section{The link between PVD and glaucoma}

Studies of potential relationships between different health conditions and glaucoma led to much controversy in the literature. One of the main causes of this hot debate was the fact that authors used the term glaucoma sometimes for an IOP increase (a risk factor for GON) and sometimes for GON. All the risk factors for arteriosclerosis were also risk factors for an IOP increase (Fig. 7). However, at a given IOP level, they did not further increase the risk for GON. We knew that OBF was altered in glaucoma patients, particularly in those progressing despite normal or normalised IOP [84, 277, 278], but hypoxia, e.g. in the context of a non-arteritic anterior ischaemic optic neuropathy, led to $\mathrm{ONH}$ atrophy but not to GON [279] (in contrast to arteritic ischaemic optic neuropathy [280]). We were therefore looking for a potential link [200] between OBF [281] and GON. As oxidative stress [282-284] was a potential candidate $[248,270]$, we quantified oxidative stress indirectly by measuring DNA breaks with a comet assay [285-288]. Patients with PVD had a significantly higher rate of DNA breaks [285, 289] (Fig. 6b).

We formulated the hypothesis that GON might be the result of repeated small reperfusion injuries [290, 291], in which an unstable oxygen supply causes oxidative stress in the mitochondria of the neural tissue [292]. Oxygen supply is instable if oxygen saturation is unstable, for example, in subjects with sleep apnoea. But oxygen supply was also unstable if the blood supply was unstable [293]. This was the case if IOP fluctuated on a high level or BP on a low level, which may exceed the capacity of autoregulation from time to time [247]. The blood supply was particularly unstable in cases with disturbed autoregulation [173], and this was the case in subjects with PVD [89, 203]. Regulation of blood flow is necessary to adapt to different conditions. Regulation of OBF compensates for varying perfusion

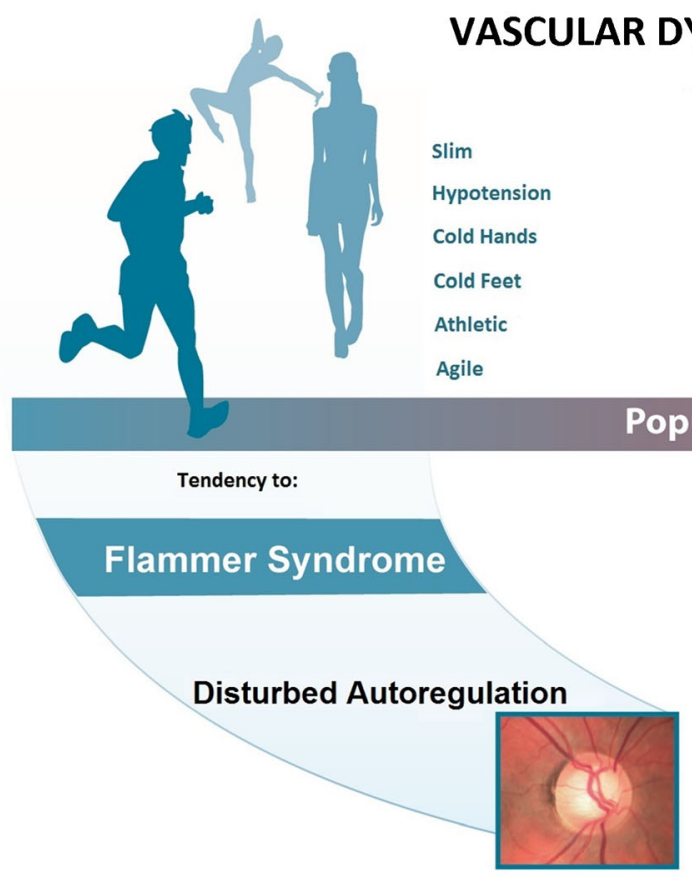

NTG

Fig. 7 The two extremes in terms of body weight, blood pressure, etc., lead to different types of vascular dysfunctions. Interestingly, both types of dysfunction can lead to very similar end points as exemplified on the development of glaucomatous damage. The Flammer syndrome increases 
pressures (autoregulation), adapts to the retinal activity (neurovascular coupling) and keeps the back of the eye at a constant temperature (thermoregulation) $[173,294]$. The regulation was disturbed in some glaucoma patients [295] and in healthy PVD subjects as measured in retroocular vessels [193], in the central retinal artery [89] and in the choroid [194, 203]. This led to the description of a new pathogenetic concept of GON [200, 201, 247, 296, 297] (Fig. 6d) and to new therapeutic approaches $[80,129,293,298-302]$. It also influenced our preference for certain IOP-lowering drugs [303, 304].

The published effects of drugs on the visual fields of glaucoma patients also generated some confusion. We needed to separate clearly the effect of lowering IOP from direct effects of the drugs on the visual fields. We further needed to separate drug-induced improvements or deteriorations from their impacts on longterm progression of visual fields. As mentioned before, acetazolamide [56, 57], nifedipine [63, 64] and, to some extent, magnesium [301] improved visual fields independently of their IOP-lowering effects. Pindolol [305], carteolol [134, 306] and betaxolol [307, 308] however had a better effect than timolol on the long-term progression, despite a similar or even weaker IOP-reducing effect [303]. It therefore became clear that IOP could not be the only modifiable risk factor for glaucoma [80, 298, 309].

\section{Psychological characteristics of PVD subjects}

The psyche has more influence on the eye than generally assumed [310]. NTG patients showed generally more complaints and were more emotionally unstable than the controls [311, 312]. Therefore, we also searched for psychological characteristics of healthy PVD subjects. A population survey revealed a disposition for socialisation with high-power anger suppression for PVD subjects and for the non-PVD subjects, a tendency towards outwardly expressed anger [313]. Nevertheless, our knowledge about the psychological characteristics of subjects with FS is still very limited.

\section{Retinal venous pressure}

In the 1990s, we already suspected the veins to also be essentially involved in the vascular dysregulations of glaucoma patients [201], but we could not prove this until much later, when we measured retinal venous pressure (RVP) (Fig. 3e,f). Whilst RVP is equal to or slightly above IOP in healthy people, it is often markedly increased in patients with eye or systemic diseases. We postulated that besides mechanical obstructions, the main cause of RVP elevation may be local dysregulations of retinal veins, particularly constrictions induced by endothelin-1 (ET-1) [221]. A local increase of ET-1 can result from a high plasma level, as ET-1 can diffuse from the fenestrated capillaries of the choroid into the $\mathrm{ONH}$, bypassing the blood-retinal barrier [204] (Fig. 5a). A local increase can also result from increased local production, either by a sick neighbouring artery (Fig. 5c) or by hypoxic retinal tissue. Generally, the main factors increasing ET-1 are inflammations and hypoxia, either locally or in remote organs.

RVP was increased in glaucoma [314], and correspondingly, the pulse amplitude in these veins was lower [315]. Eyes with optic disc haemorrhages did not have higher RVP but did have lower retinal arterial pressures in comparison to both the contralateral eyes and eyes of control patients matched for BP [253]. This indicated that the haemorrhages were due to a hypoxia-induced breakdown of the barrier rather than to mechanical ruptures of a retinal vessel [206]. RVP was increased in diabetic retinopathy [316] and in high-mountain disease [244]. RVP was, as expected, increased in eyes with RVO. Surprisingly, RVP was also increased in the clinically non-affected fellow eyes [317]. This contradicted the theory of a thrombus as the primary cause of RVO and supported the hypothesis of a local vasoconstriction of retinal veins at their exit (Fig. 5b,c). RVP was not higher in chronic smokers than in non-smokers [318] but was increased in subjects with FS [319], and CCBs reduced RVP in these FS-positive subjects [320]. Based on these observations, we considered an increased RVP less a consequence of structural alterations but more of a dysregulation of retinal veins. FS seemed to be one of the causes for such a venous dysregulation. A high RVP decreases perfusion pressure, which heightens the risk for hypoxia. A high level of RVP may not only be a consequence but also a potential cause of a RVO. This is because high RVP increases hypoxia and hypoxia stimulates ET production and thereby increases RVP, causing a vicious circle. An increase of RVP also elevates transmural pressure, which in turn heightens the risk for retinal oedema. Patients with RVO-related macular oedema that did not respond to anti-VEGF therapy showed an increase of plasma ET after treatment [217], indicating that hypoxia was a main player in such cases. Narrow retinal arteries and, particularly, dilated retinal veins are known risk indicators for future cardiovascular events [165]. Because the major cause for such a retinal venous dilatation is an increased RVP, RVP may likely turn out to be an even stronger predictor [221]. 


\section{Flammer syndrome}

The term PVD was better than VS but still not satisfactory, as it became more and more obvious that a syndrome existed that encompassed a holistic altered response of the body including vascular aspects and other signs and symptoms. In addition, PVD was often confused with posterior vitreous detachment. For this reason, one of us (KK), together with some other authors, introduced in 2013 the new term Flammer syndrome. After the term had already been mentioned in different contexts [297, 321], it was elaborated in details in reviews [1, 3] and in book chapters [322].

FS describes a phenotype characterised by the presence of PVD [2] together with a cluster of symptoms and signs that may occur in healthy people as well as people with disease. Typically, the blood vessels of the subjects with FS react differently to a number of stimuli, such as cold, physical, chemical or emotional stress. Nearly all organs, particularly the eye, can be involved. Although the syndrome potentially has some advantages for the person affected, e.g. less likelihood becoming arteriosclerotic, FS potentially contributes to certain diseases, such as normal-tension glaucoma. The syndrome occurs more often in women than in men, in slender people more often than in obese subjects, in people with indoor rather than outdoor jobs and in academics more often than in blue-collar workers [279]. Affected subjects tend to have cold extremities, low blood pressure, prolonged sleep onset time, shifted circadian rhythm, reduced feeling of thirst, altered drug sensitivity and increased general sensitivity, including pain sensitivity (Fig. 8). The plasma level of endothelin-1 is slightly increased, and the gene expression in lymphocytes is quantitatively changed. In the eye, the retinal vessels are stiffer and their spatial variability is larger; the autoregulation of ocular blood flow is decreased. Glaucoma patients with FS have an increased frequency of optic disc haemorrhages, activated retinal astrocytes, elevated retinal venous pressure, optic nerve compartmentalisation, fluctuating diffuse visual field defects and elevated oxidative stress.

\section{Conclusion}

The evolution of the present knowledge of FS stretched over several decades. It started with the observation of unexplained phenomena in the outcome of perimetry in glaucoma patients pointing towards the role of OBF. As OBF measurements were unsatisfactory at that time, nailfold capillaroscopy turned out to be a useful substitute until new methods to quantify OBF were introduced. The dynamic retinal vessel analyser finally allowed demonstrating vascular dysregulation. In vitro examinations of ocular vessels and analyses of gene expression of lymphocytes rendered an important basis for understanding the vascular dysfunction. Careful analysis of related symptoms and signs stimulated the initiation of a number of scientific studies. With growing knowledge, the terminology changed from vasospasm over vasospastic syndrome to primary vascular dysregulation and finally to Flammer syndrome.
Fig. 8 Illustrations of frequent, but not compulsory, symptoms of subjects with Flammer syndrome (modified after ref. [3])

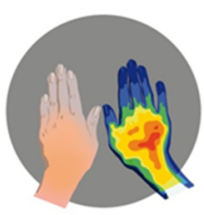

Cold extremities

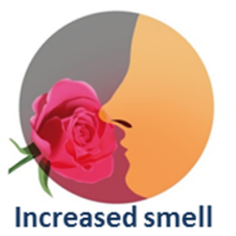
sensitivity

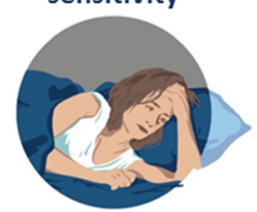

Prolonged sleep onset time

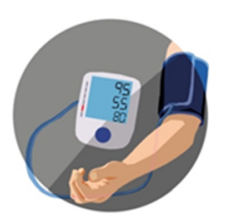

Low blood pressure

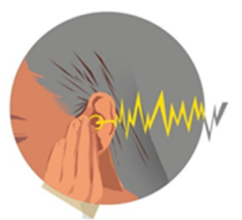

Tinnitus

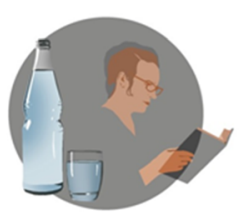

Reduced thirst

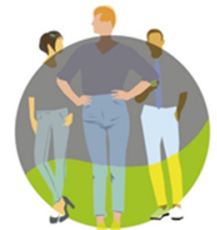

Slim

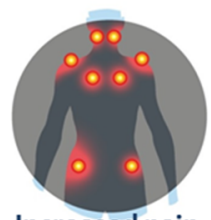

Increased pain sensitivity

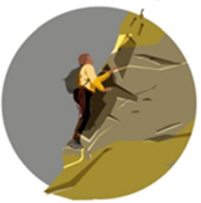

Ambitious, succesful

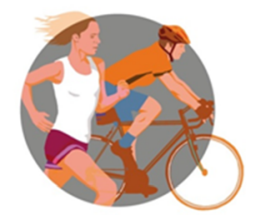

Sportive

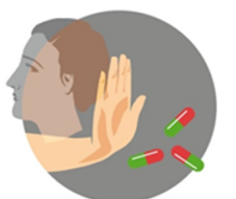

Altered drug sensitivity

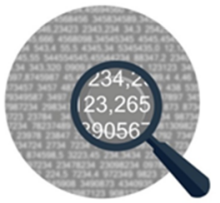

Perfectionist, intelectual 
Additional research proved the involvement of FS not just in glaucoma but also in many other eye diseases such as vascular occlusions and retinitis pigmentosa, but also in systemic diseases such as MS. Establishing the risk for related diseases may lead to predictive and preventive diagnostics, and treatment tailored to the person. This may be particularly relevant for young FS individuals.

The FS is obviously not a new phenomenon. We can only speculate why it has not been recognised earlier. Several aspects may have been jointly responsible: (a) we focus often just on one organ; (b) we tend to prefer monocausal aetiologies; (c) BF dysfunction due to structural changes are easier to observe then changeable functional dysregulations; (d) we tend to extrapolate relationships, although they are often $U$ shaped; and (e) methods to measure BF in vivo or to test blood vessels ex vivo and to quantify gene expression have been markedly improved in the last few decades.

We emphasise that what we described here is only the state of present knowledge. We are convinced that the future will add additional aspects and also correct some of the present assumptions. Science is an ongoing process, and therefore, the understanding of the syndrome and its impact in medicine will further develop. However, our patients suffering from FS symptoms and FS-related diseases deserve to benefit now from the present knowledge, even though it is still limited. Patients are very pleased when they realise that they do not suffer from numerous independent symptoms and sings but rather from one syndrome. They are thankful for information on how they can improve the situation by adapting lifestyle and nutrition. A communication between the different physicians involved makes it possible to avoid unfavourable drugs and, if necessary, to replace them by a treatment adapted to FS in terms of both drug selection and dose.

\section{Abbreviations:}

ABC, ATP-binding cassette; ARAMs, activated retinal astrocytes and Müller cells; BF, blood flow; BMI, body mass index; BP, systemic blood pressure; CCBs, calcium channel blockers; CDI, colour Doppler imaging; DNA, deoxyribonucleic acid; ECG, electrocardiogram; ET, endothelin; FS, Flammer syndrome; GON, glaucomatous optic neuropathy; HTG, high-tension glaucoma; IOP, intraocular pressure; LHON, Leber s hereditary optic neuropathy; MMP, metalloproteinase; MRI, magnetic resonance imaging; MS, multiple sclerosis; NTG, normal-tension glaucoma; OBF, ocular blood flow; OCT, optical coherence tomography; ONCS, optic nerve compartment syndrome; $\mathrm{ONH}$, optic nerve head; PVD, primary vascular dysregulation; RVO, retinal vein occlusion; RVP, retinal venous pressure; VEGF, vascular endothelial growth factor; VS, vasospastic syndrome

\section{Compliance with ethical standards}

Conflict of interest The authors declare that they have no conflict of interest.

Open Access This article is distributed under the terms of the Creative Commons Attribution 4.0 International License (http:// creativecommons.org/licenses/by/4.0/), which permits unrestricted use, distribution, and reproduction in any medium, provided you give appropriate credit to the original author(s) and the source, provide a link to the Creative Commons license, and indicate if changes were made.

\section{References}

1. Konieczka K, Ritch R, Traverso CE, Kim DM, Kook MS, Gallino A, et al. Flammer syndrome. EPMA J. 2014;5(1):11.

2. Flammer J, Konieczka K, Flammer AJ. The primary vascular dysregulation syndrome: implications for eye diseases. EPMA J. 2013;4(1):14.

3. Konieczka K, Flammer J. Phenomenology and clinical relevance of the Flammer syndrome. Klin Monatsbl Augenheilkd. 2016;233(12):1331-6.

4. Goldmann H. Demonstration unseres neuen Projektionskugelperimeters samt theoretischen und klinischen Bemerkung über Perimetrie. Ophthalmologica. 1946;111(2-3): 187-92.

5. Fankhauser F, Koch P, Roulier A. On automation of perimetry. Albrecht Von Graefes Arch Klin Exp Ophthalmol. 1972;184(2): 126-50.

6. Spahr J, Fankhauser F, Jenni A, Bebie H. Practical experiences with the Octopus automatic perimeter (author's transl). Klin Monatsbl Augenheilkd. 1978;172(4):470-7.

7. Niesel P, Flammer J. Correlations between intraocular pressure, visual field and visual acuity, based on 11 years of observations of treated chronic glaucomas. Int Ophthalmol. 1980;3(1):31-5.

8. Flammer J, Eppler E, Niesel P. Quantitative perimetry in the glaucoma patient without local visual field defects. Graefes Arch Clin Exp Ophthalmol. 1982;219(2):92-4.

9. Flammer J, Haefliger IO, Orgul S, Resink T. Vascular dysregulation: a principal risk factor for glaucomatous damage? J Glaucoma. 1999;8(3):212-9.

10. Zhang X, Erb C, Flammer J, Nau WM. Absolute rate constants for the quenching of reactive excited states by melanin and related 5 , 6-dihydroxyindole metabolites: implications for their antioxidant activity. Photochem Photobiol. 2000;71(5):524-33.

11. Nau-Staudt K, Nau WM, Haefliger IO, Flammer J. Dependence of lipid peroxidation on pigmentation of the porcine iris. Klin Monatsbl Augenheilkd. 2001;218(5):341-4.

12. Flammer J. Theoretische Grundlagen der automatischen Perimetrie. In: Gloor, B. (Hrsg.): Automatische Perimetrie, Bücherei des Augenarztes. Enke Verlag, Stuttgart. 1987. Band $110,1-31$.

13. Flammer J, Drance SM, Jenni A, Bebie H. JO and STATJO: programs for investigating the visual field with the Octopus automatic perimeter. Can J Ophthalmol. 1983;18(3):115-7.

14. Flammer J, Jenni A, Bebié H, Keller B. The Octopus glaucoma G1 program. Glaucoma. 1987;9:67-72.

15. Messmer C, Flammer J. Octopus program G1X. Ophthalmologica. 1991;203(4):184-8.

16. Zulauf M, LeBlanc RP, Flammer J. Normal visual fields measured with Octopus-program G1. II. Global visual field indices. Graefes Arch Clin Exp Ophthalmol. 1994;232(9):516-22. 
17. Haas A, Flammer J, Schneider U. Influence of age on the visual fields of normal subjects. Am J Ophthalmol. 1986;101(2):199 203.

18. Rutishauser C, Flammer J, Haas A. The distribution of normal values in automated perimetry. Graefes Arch Clin Exp Ophthalmol. 1989;227(6):513-7.

19. Flammer J, Drance SM, Augustiny L, Funkhouser A. Quantification of glaucomatous visual field defects with automated perimetry. Invest Ophthalmol Vis Sci. 1985;26(2):176-81.

20. Flammer J. The concept of visual field indices. Graefes Arch Clin Exp Ophthalmol. 1986;224(5):389-92.

21. Funkhouser AT, Fankhauser F. A comparison of the mean defect and mean deviation indices within the central 28 degrees of the glaucomatous visual field. Jpn J Ophthalmol. 1990;34(4):414-20.

22. Rutishauser C, Flammer J. Retests in static perimetry. Graefes Arch Clin Exp Ophthalmol. 1988;226(1):75-7.

23. Funkhouser A, Fankhauser F. The effects of weighting the "mean defect" visual field index according to threshold variability in the central and midperipheral visual field. Graefes Arch Clin Exp Ophthalmol. 1991;229(3):228-31.

24. Funkhouser AT, Fankhauser F. A comparison of unweighted and fluctuation-weighted indices (within the central 28 degrees of glaucomatous visual fields measured with the Octopus automated perimeter). Int Ophthalmol. 1991;15(5):347-51.

25. Bebie H, Flammer J, Bebie T. The cumulative defect curve: separation of local and diffuse components of visual field damage. Graefes Arch Clin Exp Ophthalmol. 1989;227(1):9-12.

26. Kaufmann H, Flammer J. The Bebie curve (cumulative defect curve) for differentiating local and diffuse visual field defects. Fortschr Ophthalmol. 1989;86(6):687-91.

27. Funkhouser A, Flammer J, Fankhauser F, Hirsbrunner HP. A comparison of five methods for estimating general glaucomatous visual field depression. Graefes Arch Clin Exp Ophthalmol. 1992;230(2):101-6.

28. Marra G, Flammer J. The learning and fatigue effect in automated perimetry. Graefes Arch Clin Exp Ophthalmol. 1991;229(6):5014.

29. Weijland A, Fankhauser F, Bebie H, Flammer J. Automated perimetry. Fifth ed. Haag-Streit AG, Switzerland: Visual Field Digest; 2005.

30. Flammer J, Drance SM. Correlation between color vision scores and quantitative perimetry in suspected glaucoma. Arch Ophthalmol. 1984;102(1):38-9.

31. Zulauf M, Flammer J. Correlation of spatial contrast sensitivity and visual fields in glaucoma. Graefes Arch Clin Exp Ophthalmol. 1993;231(3):146-50.

32. Guthauser U, Flammer J, Niesel P. The relationship between the visual field and the optic nerve head in glaucomas. Graefes Arch Clin Exp Ophthalmol. 1987;225(2):129-32.

33. Flammer J, Bebie H. Lens opacity meter: a new instrument to quantify lens opacity. Ophthalmologica. 1987;195(2):69-72.

34. De Natale R, Flammer J. Lens opacity: a population study. Int Ophthalmol. 1992;16(1):1-5.

35. Franklin SL, Flammer J, De Natale R, Rutishuser C. The transparency of the lens: a comparison between diabetic and non-diabetic patients. Int Ophthalmol. 1990;14(2):73-6.

36. Messmer C, Yao K, Stumpfig D, Flammer J. The opacity lens meter 701: clinical experiences. Klin Monatsbl Augenheilkd. 1990;196(5):310-1.

37. De Natale R, Flammer J, Zulauf M, Bebie T. Influence of age on the transparency of the lens in normals: a population study with help of the lens opacity meter 701. Ophthalmologica. 1988;197(1):14-8.

38. Guthauser U, Flammer J. Quantifying visual field damage caused by cataract. Am J Ophthalmol. 1988;106(4):480-4.
39. Yao K, Flammer J. Relationship cataract density and visual field damage. Eur J Ophthalmol. 1993;3(1):1-5.

40. Yao K, Flammer J. Influence of cataract on automated perimetry. Zhonghua Yan Ke Za Zhi. 1993;29(1):13-5.

41. Gasser P, Flammer J. Optic neuropathy of Graves' disease. A report of a perimetric follow-up. Ophthalmologica. 1986;192(1): 22-7.

42. Fankhauser 2nd F, Flammer J. Puptrak 1.0 - a new semiautomated system for pupillometry with the Octopus perimeter: a preliminary report. Doc Ophthalmol. 1989;73(3):235-48.

43. Rabineau PA, Flammer J. Sources of error in automated static perimetry. Klin Monatsbl Augenheilkd. 1989;194(5):307-19.

44. Kaiser HJ, Flammer J. Visual field atlas. Basel: Buser Printing Company; 1992.

45. Kaiser HJ, Flammer J, Stumpfig D. Significance of the peripheral visual field for diagnosis of glaucoma. Klin Monatsbl Augenheilkd. 1992;200(1):17-20.

46. Flammer J, Drance SM, Fankhauser F, Augustiny L. Differential light threshold in automated static perimetry. Factors influencing short-term fluctuation. Arch Ophthalmol. 1984;102(6):876-9.

47. Fankhauser F, Bebie H, Flammer J. Threshold fluctuations in the Humphrey field analyzer and in the Octopus automated perimeter. Invest Ophthalmol Vis Sci. 1988;29(9):1466.

48. Haefliger IO, Flammer J. Increase of the short-term fluctuation of the differential light threshold around a physiologic scotoma. Am J Ophthalmol. 1989;107(4):417-20.

49. Haefliger IO, Flammer J. Fluctuation of the differential light threshold at the border of absolute scotomas. Comparison between glaucomatous visual field defects and blind spots. Ophthalmology. 1991;98(10):1529-32.

50. Flammer J, Drance SM, Zulauf M. Differential light threshold. Short- and long-term fluctuation in patients with glaucoma, normal controls, and patients with suspected glaucoma. Arch Ophthalmol. 1984;102(5):704-6.

51. Flammer J, Fluctuations in the visual field. In: Drance, S.M. und Anderson, D.R. (Hrsg.): Automated perimetry in glaucoma. Grune and Stratton, Orlando. (1985) 161-73.

52. Flammer J, Drance SM, Schulzer M. Covariates of the long-term fluctuation of the differential light threshold. Arch Ophthalmol. 1984;102(6):880-2.

53. Haas A, Flammer J. Influence of diazepam on the outcome of automated perimetry. In: Heijl A, Greve EL, editors. Proceedings of the 6th Int. visual field symposium. Dordrecht: Dr W Junk Publishers ; 1986.ISBN 9061935245

54. Zulauf M, Flammer J, Signer C. The influence of alcohol on the outcome of automated static perimetry. Graefes Arch Clin Exp Ophthalmol. 1986;224(6):525-8.

55. Gasser P, Flammer J. Influence of vasospasm on visual function Doc Ophthalmol. 1987;66(1):3-18.

56. Flammer J, Drance SM. Reversibility of a glaucomatous visual field defect after acetazolamide therapy. Can J Ophthalmol. 1983;18(3):139-41.

57. Flammer J, Drance SM. Effect of acetazolamide on the differential threshold. Arch Ophthalmol. 1983;101(9):1378-80.

58. Gasser P, Flammer J, Guthauser U, Mahler F. Do vasospasms provoke ocular diseases? Angiology. 1990;41(3):213-20.

59. Flammer J. Psychophysical mechanisms and treatment of vasospastic disorders in normal-tension glaucoma. Bull Soc Belge Ophtalmol. 1992;244:129-34.

60. Osusky R, Schoetzau A, Flammer J. Variations in the blood flow of the human optic nerve head. Eur J Ophthalmol. 1997;7(4):364 9 .

61. Osusky R, Rohr P, Schotzau A, Flammer J. Nocturnal dip in the optic nerve head perfusion. Jpn J Ophthalmol. 2000;44(2):12831. 
62. Pillunat LE, Lang GK, Harris A. The visual response to increased ocular blood flow in normal pressure glaucoma. Surv Ophthalmol. 1994;(38 Suppl):S139-47. discussion S47-8

63. Gasser P, Flammer J. Short- and long-term effect of nifedipine on the visual field in patients with presumed vasospasm. J Int Med Res. 1990;18(4):334-9.

64. Gaspar AZ, Flammer J, Hendrickson P. Influence of nifedipine on the visual fields of patients with optic-nerve-head diseases. Eur J Ophthalmol. 1994;4(1):24-8.

65. Saner H, Wurbel H, Mahler F, Flammer J, Gasser P. Microvasculatory evaluation of vasospastic syndromes. Adv Exp Med Biol. 1987;220:215-8.

66. Flammer J, Guthauser U, Mahler F. Do ocular vasospasms help cause low-tension glaucoma? Doc Ophthalmol Proc Ser. 1987;49: 397-9.

67. Drance SM, Douglas GR, Wijsman K, Schulzer M, Britton RJ. Response of blood flow to warm and cold in normal and lowtension glaucoma patients. Am J Ophthalmol. 1988;105(1):35-9.

68. Gasser P, Flammer J. Blood-cell velocity in the nailfold capillaries of patients with normal-tension and high-tension glaucoma. Am J Ophthalmol. 1991;111(5):585-8.

69. Guthauser U, Flammer J, Mahler F. The relationship between digital and ocular vasospasm. Graefes Arch Clin Exp Ophthalmol. 1988;226(3):224-6.

70. Mozaffarieh M, Osusky R, Schotzau A, Flammer J. Relationship between optic nerve head and finger blood flow. Eur J Ophthalmol. 2010;20(1):136-41.

71. Flammer J, Pache M, Resink T. Vasospasm, its role in the pathogenesis of diseases with particular reference to the eye. Prog Retin Eye Res. 2001;20(3):319-49.

72. Gasser P, Flammer J, Mahler F. Is the evidence of vasospasms in the eye the expression of a generalized vasospastic disorder? In: Elsevier Science Publisher BV, Advances in Vascular Pathology. 1989:1215-20.

73. Kaiser HJ, Flammer J. Systemic hypotension: a risk factor for glaucomatous damage? Ophthalmologica. 1991;203(3):105-8.

74. Kaiser HJ, Flammer J, Graf T, Stumpfig D. Systemic blood pressure in glaucoma patients. Graefes Arch Clin Exp Ophthalmol. 1993;231(12):677-80.

75. Orgul S, Kaiser HJ, Flammer J, Gasser P. Systemic blood pressure and capillary blood-cell velocity in glaucoma patients: a preliminary study. Eur J Ophthalmol. 1995;5(2):88-91.

76. Romerio SC, Linder L, Flammer J, Haefeli WE. Correlation between apolipoprotein B and endothelin-1-induced vasoconstriction in humans. Peptides. 2000;21(6):871-4.

77. Gass A, Flammer J, Linder L, Romerio SC, Gasser P, Haefeli WE. Inverse correlation between endothelin-1-induced peripheral microvascular vasoconstriction and blood pressure in glaucoma patients. Graefes Arch Clin Exp Ophthalmol. 1997;235(10):634-8.

78. Pache M, Dubler B, Flammer J. Peripheral vasospasm and nocturnal blood pressure dipping - two distinct risk factors for glaucomatous damage? Eur J Ophthalmol. 2003;13(3):260-5.

79. Gugleta K, Orgul S, Stumpfig D, Dubler B, Flammer J. Fludrocortisone in the treatment of systemic hypotension in primary open-angle glaucoma patients. Int Ophthalmol. 1999;23(1): 25-30.

80. Mozaffarieh M, Flammer J. Is there more to glaucoma treatment than lowering IOP? Surv Ophthalmol. 2007;52(Suppl 2):S174-9.

81. Kaiser HJ, Schotzau A, Flammer J. Blood-flow velocities in the extraocular vessels in normal volunteers. Am J Ophthalmol. 1996;122(3):364-70.

82. Kaiser HJ, Schoetzau A, Flammer J. The frequency distribution of blood-flow velocities in the extraocular vessels. Graefes Arch Clin Exp Ophthalmol. 1996;234(9):537-41.
83. Senn BC, Kaiser HJ, Schotzau A, Flammer J. Reproducibility of color Doppler imaging in orbital vessels. Ger J Ophthalmol. 1996;5(6):386-91.

84. Kaiser HJ, Schoetzau A, Stumpfig D, Flammer J. Blood-flow velocities of the extraocular vessels in patients with high-tension and normal-tension primary open-angle glaucoma. Am J Ophthalmol. 1997;123(3):320-7.

85. Grieshaber MC, Kocak I, Dubler B, Flammer J, Orgul S. Retrobulbar blood flow in patients with cataract. Br J Ophthalmol. 2006;90(12):1512-5.

86. Senn B, Orgul S, Keller U, Dickermann D, Dubler B, Vavrecka J, et al. Retrobulbar and peripheral capillary blood flow in hypercholesterolemic subjects. Am J Ophthalmol. 1999;128(3):310-6.

87. Kaiser HJ, Schoetzau A, Flammer J. Blood flow velocity in the extraocular vessels in chronic smokers. Br J Ophthalmol. 1997;81(2):133-5.

88. Gherghel D, Orgul S, Gugleta K, Flammer J. Retrobulbar blood flow in glaucoma patients with nocturnal over-dipping in systemic blood pressure. Am J Ophthalmol. 2001;132(5):641-7.

89. Gherghel D, Orgul S, Dubler B, Lubeck P, Gugleta K, Flammer J. Is vascular regulation in the central retinal artery altered in persons with vasospasm? Arch Ophthalmol. 1999;117(10):1359-62.

90. Kaiser HJ, Stumpfig D, Flammer J. Short-term effect of dipyridamole on blood flow velocities in the extraocular vessels. Int Ophthalmol. 1995;19(6):355-8.

91. Hintermann E, Erb C, Talke-Messerer C, Liu R, Tanner H, Flammer J, et al. Expression of the melanin-concentrating hormone receptor in porcine and human ciliary epithelial cells. Invest Ophthalmol Vis Sci. 2001;42(1):206-9.

92. Liu R, Hintermann E, Erb C, Tanner H, Flammer J, Eberle AN, et al. Modulation of $\mathrm{Na} / \mathrm{K}$-ATPase activity by isoproterenol and propranolol in human non-pigmented ciliary epithelial cells. Klin Monatsbl Augenheilkd. 2001;218(5):363-5.

93. Haufschild T, Nava E, Meyer P, Flammer J, Luscher TF, Haefliger IO. Spontaneous calcium-independent nitric oxide synthase activity in porcine ciliary processes. Biochem Biophys Res Commun. 1996;222(3):786-9.

94. Liu R, Flammer J, Luscher TF, Haefliger IO. Beta-adrenergic agonist-induced nitrite production in isolated pig ciliary processes. Graefes Arch Clin Exp Ophthalmol. 1998;236(8):613-6.

95. Meyer P, Champion C, Schlotzer-Schrehardt U, Flammer J, Haefliger IO. Localization of nitric oxide synthase isoforms in porcine ocular tissues. Curr Eye Res. 1999;18(5):375-80.

96. Liu R, Flammer J, Haefliger IO. Isoproterenol, forskolin, and cAMP-induced nitric oxide production in pig ciliary processes. Invest Ophthalmol Vis Sci. 1999;40(8):1833-7.

97. Fleischhauer JC, Beny JL, Flammer J, Haefliger IO. NO/ cGMP pathway activation and membrane potential depolarization in pig ciliary epithelium. Invest Ophthalmol Vis Sci. 2000;41(7):1759-63.

98. Fleischhauer JC, Flammer J, Haefliger IO. Membrane potential depolarization in the porcine ciliary epithelium evoked by nitric oxide. Klin Monatsbl Augenheilkd. 2000;216(5):321-3.

99. Haufschild T, Tschudi MR, Flammer J, Luscher TF, Haefliger IO. Nitric oxide production by isolated human and porcine ciliary processes. Graefes Arch Clin Exp Ophthalmol. 2000;238(5): 448-53.

100. Liu R, Flammer J, Haefliger IO. Brimonidine and inhibition of nitrite production in isolated porcine ciliary processes. Klin Monatsbl Augenheilkd. 2001;218(5):348-50.

101. Pellanda N, Flammer J, Haefliger IO. L-NAME- and U 46619induced contractions in isolated porcine ciliary arteries versus vortex veins. Klin Monatsbl Augenheilkd. 2001;218(5):366-9. 
102. Fleischhauer JC, Beny JL, Flammer J, Haefliger IO. Cyclic AMP and anionic currents in porcine ciliary epithelium. Klin Monatsbl Augenheilkd. 2001;218(5):370-2.

103. Liu R, Flammer J, Haefliger IO. Forskolin upregulation of NOS I protein expression in porcine ciliary processes: a new aspect of aqueous humor regulation. Klin Monatsbl Augenheilkd. 2002;219(4):281-3.

104. Liu R, Wu R, Flammer J, Haefliger IO. Inhibition by brimonidine of forskolin-induced nitrite production in isolated pig ciliary processes. Invest Ophthalmol Vis Sci. 2002;43(8):2727-31.

105. Wu R, Flammer J, Haefliger I. Transepithelial short circuit currents in human and porcine isolated ciliary bodies: effect of acetazolamide and epinephrine. Klin Monatsbl Augenheilkd. 2003;220(3):156-60.

106. Wu R, Flammer J, Yao K, Haefliger IO. Reduction of nitrite production by endothelin-1 in isolated porcine ciliary processes. Exp Eye Res. 2003;77(2):189-93.

107. Wu R, Yao K, Flammer J, Haefliger IO. Role of anions in nitric oxide-induced short-circuit current increase in isolated porcine ciliary processes. Invest Ophthalmol Vis Sci. 2004;45(9):321322.

108. Ni Y, Wu R, Xu W, Maecke H, Flammer J, Haefliger IO. Effect of cAMP on porcine ciliary transepithelial short-circuit current, sodium transport, and chloride transport. Invest Ophthalmol Vis Sci. 2006;47(5):2065-74.

109. Fasler-Kan E, Barteneva NS, Ketterer S, Wunderlich K, Reschner A, Nurzhanova A, et al. Human cytokines activate JAK-STAT signaling pathway in porcine ocular tissue. Xenotransplantation. 2013;20(6):469-80.

110. Fleischhauer JC, Liu R, Elena PP, Flammer J, Haefliger IO. Topical ocular instillation of nitric oxide synthase inhibitors and intraocular pressure in rabbits. Klin Monatsbl Augenheilkd. 2001;218(5):351-3.

111. Fang L, Li J, Flammer J, Neutzner A. MARCH5 inactivation supports mitochondrial function during neurodegenerative stress. Front Cell Neurosci. 2013;7:176.

112. Benischke AS, Hemion C, Flammer J, Neutzner A. Proteasomemediated quality control of S-nitrosylated mitochondrial proteins. Mitochondrion. 2014;17:182-6.

113. Fang L, Hemion C, Pinho Ferreira Bento AC, Bippes CC, Flammer J, Neutzner A. Mitochondrial function in neuronal cells depends on $\mathrm{p} 97 / \mathrm{VCP} / \mathrm{Cdc} 48$-mediated quality control. Front Cell Neurosci. 2015;9:16

114. Yao K, Tschudi M, Flammer J, Luscher TF. Endotheliumdependent regulation of vascular tone of the porcine ophthalmic artery. Invest Ophthalmol Vis Sci. 1991;32(6):1791-8.

115. Haefliger IO, Meyer P, Flammer J, Luscher TF. The vascular endothelium as a regulator of the ocular circulation: a new concept in ophthalmology? Surv Ophthalmol. 1994;39(2):123-32.

116. Haefliger IO, Flammer J, Luscher TF. Heterogeneity of endothelium-dependent regulation in ophthalmic and ciliary arteries. Invest Ophthalmol Vis Sci. 1993;34(5):1722-30.

117. Haefliger IO, Flammer J, Luscher TF. Nitric oxide and endothelin1 are important regulators of human ophthalmic artery. Invest Ophthalmol Vis Sci. 1992;33(7):2340-3.

118. Konieczka K, Flammer AJ, Neutzner A, Schoetzau A, Binggeli T, Flammer J. Refractoriness to the effect of endothelin-1 in porcine ciliary arteries. J Ocul Pharmacol Ther. 2013;29(5):488-92.

119. Savaskan E, Loffler KU, Meier F, Muller-Spahn F, Flammer J, Meyer P. Immunohistochemical localization of angiotensinconverting enzyme, angiotensin II and AT1 receptor in human ocular tissues. Ophthalmic Res. 2004;36(6):312-20.

120. Dubey RK, Flammer J, Luscher TF. Angiotensin II and insulin induce growth of ciliary artery smooth muscle: effects of AT1/AT2 antagonists. Invest Ophthalmol Vis Sci. 1998;39(11):2067-75.
121. Meyer P, Pache M, Loeffler KU, Brydon L, Jockers R, Flammer J, et al. Melatonin MT-1-receptor immunoreactivity in the human eye. Br J Ophthalmol. 2002;86(9):1053-7.

122. Meyer P, Flammer J, Luscher TF. Local anesthetic drugs reduce endothelium-dependent relaxations of porcine ciliary arteries. Invest Ophthalmol Vis Sci. 1993;34(9):2730-6.

123. Meyer P, Flammer J, Luscher TF. Local action of the renin angiotensin system in the porcine ophthalmic circulation: effects of ACE-inhibitors and angiotensin receptor antagonists. Invest Ophthalmol Vis Sci. 1995;36(3):555-62.

124. Meyer P, Lang MG, Flammer J, Luscher TF. Effects of calcium channel blockers on the response to endothelin-1, bradykinin and sodium nitroprusside in porcine ciliary arteries. Exp Eye Res. 1995;60(5):505-10.

125. Lang MG, Zhu P, Meyer P, Noll G, Haefliger IO, Flammer J, et al. Amlodipine and benazeprilat differently affect the responses to endothelin-1 and bradykinin in porcine ciliary arteries: effects of a low and high dose combination. Curr Eye Res. 1997;16(3):20813.

126. Meyer P, Flammer J, Luscher TF. Effect of dipyridamole on vascular responses of porcine ciliary arteries. Curr Eye Res. 1996;15(4):387-93.

127. Zhu P, Beny JL, Flammer J, Luscher TF, Haefliger IO. Relaxation by bradykinin in porcine ciliary artery. Role of nitric oxide and $\mathrm{K}(+)$-channels. Invest Ophthalmol Vis Sci. 1997;38(9):1761-7.

128. Morf T, Zhu P, Flammer J, Haefliger IO. Vasorelaxing effect of the potassium $(\mathrm{K}+)$-channel opener pinacidil in isolated porcine ciliary arteries. Klin Monatsbl Augenheilkd. 2001;218(5):338-40.

129. Dettmann ES, Luscher TF, Flammer J, Haefliger IO. Modulation of endothelin-1-induced contractions by magnesium/calcium in porcine ciliary arteries. Graefes Arch Clin Exp Ophthalmol. 1998;236(1):47-51.

130. Zhu P, Dettmann ES, Resink TJ, Luscher TF, Flammer J, Haefliger IO. Effect of ox-LDL on endothelium-dependent response in pig ciliary artery: prevention by an ET(a) antagonist. Invest Ophthalmol Vis Sci. 1999;40(5):1015-20.

131. Konieczka K, Meyer P, Schoetzau A, Neutzner A, Mozaffarieh M, Flammer J. Effect of avosentan (SPP-301) in porcine ciliary arteries. Curr Eye Res. 2011;36(2):118-24.

132. Allemann R, Flammer J, Haefliger IO. Vasoactive properties of bimatoprost in isolated porcine ciliary arteries. Klin Monatsbl Augenheilkd. 2003;220(3):161-4.

133. Kasper J, Champion C, Flammer J, Haefliger IO. Vasorelaxing properties of carteolol in isolated porcine ciliary arteries. Klin Monatsbl Augenheilkd. 2000;216(5):318-20.

134. Brogiolo G, Flammer J, Haefliger IO. The beta-blocker carteolol inhibits contractions induced by $\mathrm{KCl}$ in pig ciliary arteries: an effect modulated by extracellular $\mathrm{Ca}^{++}$. Klin Monatsbl Augenheilkd. 2002;219(4):268-72.

135. Vysniauskiene I, Allemann R, Flammer J, Haefliger IO. Vasoactive responses of U46619, PGF2alpha, latanoprost, and travoprost in isolated porcine ciliary arteries. Invest Ophthalmol Vis Sci. 2006;47(1):295-8.

136. Allemann R, Flammer J, Haefliger IO. Absence of vasoactive properties of travoprost in isolated porcine ciliary arteries. Klin Monatsbl Augenheilkd. 2003;220(3):152-5.

137. El Sherbini M, Gekkieva M, Flammer J, Haefliger IO. Effect of Xalatan $(R)$ and $\operatorname{Cosopt}(R)$ on the vascular tone of quiescent isolated pig ciliary arteries. Klin Monatsbl Augenheilkd. 2002;219(4):273-6.

138. Brogiolo G, Flammer J, Haefliger IO. Latanoprost is a vasoconstrictor in isolated porcine ciliary arteries. Klin Monatsbl Augenheilkd. 2001;218(5):373-5.

139. Pache M, Krauchi K, Haefliger IO, Wirz-Justice A, Flammer J, Meyer P. Effect of melatonin on vascular responses of porcine ciliary arteries. Curr Eye Res. 2002;24(4):313-7. 
140. Dettmann ES, Vysniauskiene I, Wu R, Flammer J, Haefliger IO. Adrenomedullin-induced endothelium-dependent relaxation in porcine ciliary arteries. Invest Ophthalmol Vis Sci. 2003;44(9): 3961-6.

141. Meyer P, Flammer J, Luscher TF. Endothelium-dependent regulation of the ophthalmic microcirculation in the perfused porcine eye: role of nitric oxide and endothelins. Invest Ophthalmol Vis Sci. 1993;34(13):3614-21.

142. Yu DY, Su EN, Cringle SJ, Yu PK. Isolated preparations of ocular vasculature and their applications in ophthalmic research. Prog Retin Eye Res. 2003;22(2):135-69.

143. Yu DY, Su EN, Cringle SJ, Morgan WH, McAllister IL, Yu PK. Local modulation of retinal vein tone. Invest Ophthalmol Vis Sci. 2016;57(2):412-9.

144. Flammer J, Weidmann P, Gluck Z, Ziegler WH, Reubi FC. Cardiovascular and endocrine profile of adrenergic neurone blockade in normal and hypertensive man. Am J Med. 1979;66(1):34-42.

145. Flammer J, Barth D. Cadiovascular effects of local timolol therapy (author's transl). Klin Monatsbl Augenheilkd. 1980;176(4):561-5.

146. Vonwil A, Landolt M, Flammer J, Bachofen H. Bronchoconstrictive side effects of timolol eye drops in patients with obstructive lung disease. Schweiz Med Wochenschr. 1981;111(19):665-9.

147. Beano F, Orgul S, Stumpfig D, Gugleta K, Flammer J. An evaluation of the effect of unoprostone isopropyl $0.15 \%$ on ocular hemodynamics in normal-tension glaucoma patients. Graefes Arch Clin Exp Ophthalmol. 2001;239(2):81-6.

148. Pache M, Meyer P, Prunte C, Orgul S, Nuttli I, Flammer J. Sildenafil induces retinal vasodilatation in healthy subjects. Br J Ophthalmol. 2002;86(2):156-8.

149. Spicher T, Orgul S, Gugleta K, Teuchner B, Flammer J. The effect of losartan potassium on choroidal hemodynamics in healthy subjects. J Glaucoma. 2002;11(3):177-82.

150. Costa VP, Harris A, Stefansson E, Flammer J, Krieglstein GK, Orzalesi N, et al. The effects of antiglaucoma and systemic medications on ocular blood flow. Prog Retin Eye Res. 2003;22(6): 769-805.

151. Haefliger IO, Lietz A, Griesser SM, Ulrich A, Schotzau A, Hendrickson $\mathrm{P}$, et al. Modulation of Heidelberg retinal flowmeter parameter flow at the papilla of healthy subjects: effect of carbogen, oxygen, high intraocular pressure, and beta-blockers. Surv Ophthalmol. 1999;43(Suppl 1):S59-65.

152. Prunte C, Flammer J, Markstein R, Rudin M. Quantification of optic nerve blood flow changes using magnetic resonance imaging. Invest Ophthalmol Vis Sci. 1995;36(1):247-51.

153. Bohdanecka Z, Orgul S, Meyer AB, Prunte C, Flammer J. Relationship between blood flow velocities in retrobulbar vessels and laser Doppler flowmetry at the optic disk in glaucoma patients. Ophthalmologica. 1999;213(3):145-9.

154. Gross S, Gugleta K, Turksever C, Ledolter A, Kochkorov A, Flammer J, et al. Analysis of risk factors for long-term glaucomatous damage development. Klin Monatsbl Augenheilkd. 2014;231(4):335-9.

155. Gugleta K, Orgul S, Flammer J. Is corneal temperature correlated with blood-flow velocity in the ophthalmic artery? Curr Eye Res. 1999;19(6):496-501.

156. Girardin F, Orgul S, Erb C, Flammer J. Relationship between corneal temperature and finger temperature. Arch Ophthalmol. 1999;117(2):166-9.

157. Gasser P, Orgul S, Dubler B, Bucheli B, Flammer J. Relation between blood flow velocities in the ophthalmic artery and in nailfold capillaries. Br J Ophthalmol. 1999;83(4):505.

158. Polunina A, Gugleta K, Kochkorov A, Katamay R, Flammer J, Orgul S. Relationship between peripheral blood flow in extremities and choroidal circulation. Klin Monatsbl Augenheilkd. 2011;228(4):302-5.
159. Gasser P, Stumpfig D, Schotzau A, Ackermann-Liebrich U, Flammer J. Body mass index in glaucoma. J Glaucoma. 1999;8(1):8-11.

160. Kavroulaki D, Gugleta K, Kochkorov A, Katamay R, Flammer J, Orgul S. Relation of body mass index and blood pressure to subjective and objective acral temperature. Klin Monatsbl Augenheilkd. 2009;226(4):328-31.

161. Orgül S, Flammer J, Gasser P. Female preponderance in normaltension glaucoma. Ann Ophthalmol. 1995;27:355-9.

162. Mozaffarieh M, Fontana Gasio P, Schotzau A, Orgul S, Flammer J, Krauchi K. Thermal discomfort with cold extremities in relation to age, gender, and body mass index in a random sample of a Swiss urban population. Popul Health Metrics. 2010;8:17.

163. Kaiser HJ, Flammer J, Burckhardt D. Silent myocardial ischemia in glaucoma patients. Ophthalmologica. 1993;207(1):6-7.

164. Waldmann E, Gasser P, Dubler B, Huber C, Flammer J. Silent myocardial ischemia in glaucoma and cataract patients. Graefes Arch Clin Exp Ophthalmol. 1996;234(10):595-8.

165. Flammer J, Konieczka K, Bruno RM, Virdis A, Flammer AJ, Taddei S. The eye and the heart. Eur Heart J. 2013;34(17):1270-8.

166. Gluck Z, Boll H, Weidmann P, Flammer J, Ziegler WH. Evaluation of autonomic neuropathy in diabetes mellitus. Comparison of clinical, functional and biochemical parameters. Klin Wochenschr. 1979;57(9):457-66.

167. Anders D, Vollenweider S, Cann J, Hofstetter M, Flammer J, Orgul S, et al. Heart-rate variability in women during 40-hour prolonged wakefulness. Chronobiol Int. 2010;27(8):1609-28.

168. Gugleta K, Zawinka C, Rickenbacher I, Kochkorov A, Katamay R, Flammer J, et al. Analysis of retinal vasodilation after flicker light stimulation in relation to vasospastic propensity. Invest Ophthalmol Vis Sci. 2006;47(9):4034-41.

169. Rickenbacher I, Gugleta K, Zawinka C, Schotzau A, Katamay R, Flammer J, et al. Response of retinal vessel diameter to flickerlight in vasospastics compared to healthy controls. Klin Monatsbl Augenheilkd. 2009;226(4):305-9.

170. Flammer AJ, Luscher TF. Human endothelial dysfunction: EDRFs. Pflugers Arch. 2010;459(6):1005-13.

171. Haefliger IO, Flammer J, Beny JL, Luscher TF. Endotheliumdependent vasoactive modulation in the ophthalmic circulation. Prog Retin Eye Res. 2001;20(2):209-25.

172. Pache M, Nagel E, Flammer J. Reproducibility of measurements with the retinal vessel analyzer under optimal conditions. Klin Monatsbl Augenheilkd. 2002;219(7):523-7.

173. Flammer J, Mozaffarieh M. Autoregulation, a balancing act between supply and demand. Can J Ophthalmol. 2008;43(3):31721.

174. Gugleta K, Kochkorov A, Waldmann N, Polunina A, Katamay R, Flammer J, et al. Dynamics of retinal vessel response to flicker light in glaucoma patients and ocular hypertensives. Graefes Arch Clin Exp Ophthalmol. 2012;250(4):589-94.

175. Grieshaber MC, Flammer J. Does the blood-brain barrier play a role in glaucoma? Surv Ophthalmol. 2007;52(Suppl 2):S115-21.

176. Golubnitschaja-Labudova O, Liu R, Decker C, Zhu P, Haefliger IO, Flammer J. Altered gene expression in lymphocytes of patients with normal-tension glaucoma. Curr Eye Res. 2000;21(5):86776.

177. Golubnitschaja O, Wunderlich K, Decker C, Monkemann H, Schild HH, Flammer J. Molecular imaging of perfusion disturbances in glaucoma. Amino Acids. 2002;23(1-3):293-9.

178. Golubnitschaja O, Yeghiazaryan K, Flammer J. Key molecular pathways affected by glaucoma pathology: is predictive diagnosis possible? EPMA J. 2010;1(2):237-44.

179. Wunderlich K, Golubnitschaja O, Pache M, Eberle AN, Flammer $\mathrm{J}$. Increased plasma levels of $20 \mathrm{~S}$ proteasome alpha-subunit in glaucoma patients: an observational pilot study. Mol Vis. 2002;8:431-5. 
180. Golubnitschaja O, Yeghiazaryan K, Liu R, Monkemann H, Leppert D, Schild H, et al. Increased expression of matrix metalloproteinases in mononuclear blood cells of normal-tension glaucoma patients. J Glaucoma. 2004;13(1):66-72.

181. Wunderlich K, Zimmerman C, Gutmann H, Teuchner B, Flammer J, Drewe J. Vasospastic persons exhibit differential expression of ABC-transport proteins. Mol Vis. 2003;9:756-61.

182. Yeghiazaryan K, Flammer J, Wunderlich K, Schild HH, Orgul S, Golubnitschaja O. An enhanced expression of ABC 1 transporter in circulating leukocytes as a potential molecular marker for the diagnostics of glaucoma. Amino Acids. 2005;28(2):207-11.

183. Golubnitschaja O, Yeghiazaryan K, Wunderlich K, Schild HH, Flammer J. Disease proteomics reveals altered basic gene expression regulation in leukocytes of normal-tension and primary openangle glaucoma patients. Proteomics Clin Appl. 2007;1(10): 1316-23.

184. Fraenkl SA, Golubnitschaja O, Yeghiazaryan K, Orgul S, Flammer J. Differences in gene expression in lymphocytes of patients with high-tension, PEX, and normal-tension glaucoma and in healthy subjects. Eur J Ophthalmol. 2013;23(6):841-9.

185. Yeghiazaryan K, Flammer J, Golubnitschaja O. Predictive molecular profiling in blood of healthy vasospastic individuals: clue to targeted prevention as personalised medicine to effective costs. EPMA J. 2010;1(2):263-72.

186. Yeghiazaryan K, Flammer J, Orgul S, Wunderlich K, Golubnitschaja O. Vasospastic individuals demonstrate significant similarity to glaucoma patients as revealed by gene expression profiling in circulating leukocytes. Mol Vis. 2009;15:2339-48.

187. Weiss J, Frankl SA, Flammer J, Grieshaber MC, Hollo G, Teuchner B, et al. No difference in genotype frequencies of polymorphisms of the nitric oxide pathway between Caucasian normal and high tension glaucoma patients. Mol Vis. 2012;18:2174-81.

188. Mahler F, Saner H, Wurbel H, Flammer J. Local cooling test for clinical capillaroscopy in Raynaud's phenomenon, unstable angina, and vasospastic visual disorders. Vasa. 1989;18(3):201-4.

189. Prunte-Glowazki A, Flammer J. Ocular vasospasm. 4: Clinical examples. Klin Monatsbl Augenheilkd. 1991;198(5):415-8.

190. Flammer J, Orgul S. Optic nerve blood-flow abnormalities in glaucoma. Prog Retin Eye Res. 1998;17(2):267-89.

191. Killer HE, Forrer A, Flammer J. Retinal vasospasm during an attack of migraine. Retina. 2003;23(2):253-4.

192. Gasser P, Flammer J, Mahler F. The use of calcium antagonists in the treatment of ocular circulation symptoms in the framework of a vasospastic syndrome. Schweiz Med Wochenschr. 1988;118(6): 201-2.

193. Gherghel D, Orgul S, Gugleta K, Gekkieva M, Flammer J. Relationship between ocular perfusion pressure and retrobulbar blood flow in patients with glaucoma with progressive damage. Am J Ophthalmol. 2000;130(5):597-605.

194. Gugleta K, Orgul S, Hasler PW, Picornell T, Gherghel D, Flammer J. Choroidal vascular reaction to hand-grip stress in subjects with vasospasm and its relevance in glaucoma. Invest Ophthalmol Vis Sci. 2003;44(4):1573-80.

195. Gugleta K, Orgul S, Hasler P, Flammer J. Circulatory response to blood gas perturbations in vasospasm. Invest Ophthalmol Vis Sci. 2005;46(9):3288-94.

196. Flammer J, Hendrickson P, Lietz A, Stumpfig D. Swivel arm perimeter for visual field testing in different body positions. Ophthalmologica. 1993;206(1):15-7.

197. Lietz A, Kaiser HJ, Stumpfig D, Flammer J. Influence of posture on the visual field in glaucoma patients and controls. Ophthalmologica. 1995;209(3):129-31.

198. Kaiser HJ, Flammer J, Wenk M, Luscher T. Endothelin-1 plasma levels in normal-tension glaucoma: abnormal response to postural changes. Graefes Arch Clin Exp Ophthalmol. 1995;233(8):484-8.
199. Kaeser P, Orgul S, Zawinka C, Reinhard G, Flammer J. Influence of change in body position on choroidal blood flow in normal subjects. Br J Ophthalmol. 2005;89(10):1302-5.

200. Grieshaber MC, Mozaffarieh M, Flammer J. What is the link between vascular dysregulation and glaucoma? Surv Ophthalmol. 2007;52(Suppl 2):S144-54.

201. Flammer J. The vascular concept of glaucoma. Surv Ophthalmol. 1994;38(Suppl):S3-6.

202. Emre M, Orgul S, Gugleta K, Flammer J. Ocular blood flow alteration in glaucoma is related to systemic vascular dysregulation. Br J Ophthalmol. 2004;88(5):662-6.

203. Hasler PW, Orgul S, Gugleta K, Vogten H, Zhao X, Gherghel D, et al. Vascular dysregulation in the choroid of subjects with acral vasospasm. Arch Ophthalmol. 2002;120(3):302-7.

204. Flammer J, Mozaffarieh M, Bebie H. Basic sciences in ophthalmology. Berlin Heidelberg: Springer-Verlag; 2013.

205. Mozaffarieh M, Flammer J. Ocular blood flow and glaucomatous optic neuropathy. Berlin, Heidelberg: Springer-Verlag; 2009.

206. Grieshaber MC, Terhorst T, Flammer J. The pathogenesis of optic disc splinter haemorrhages: a new hypothesis. Acta Ophthalmol Scand. 2006;84(1):62-8.

207. Straubhaar M, Orgul S, Gugleta K, Schotzau A, Erb C, Flammer J. Choroidal laser Doppler flowmetry in healthy subjects. Arch Ophthalmol. 2000;118(2):211-5.

208. Pache M, Kaiser HJ, Haufschild T, Lubeck P, Flammer J. Increased endothelin-1 plasma levels in giant cell arteritis: a report on four patients. Am J Ophthalmol. 2002;133(1):160-2.

209. Pache M, Schwarz HA, Kaiser HJ, Wuest P, Kloti M, Dubler B, et al. Elevated plasma endothelin-1 levels and vascular dysregulation in patients with rheumatoid arthritis. Med Sci Monit. 2002;8(9):CR616-9.

210. Pache M, Ochs J, Genth E, Mierau R, Kube T, Flammer J. Increased plasma endothelin-1 levels in fibromyalgia syndrome. Rheumatology (Oxford). 2003;42(3):493-4.

211. Haufschild T, Shaw SG, Kesselring J, Flammer J. Increased endothelin-1 plasma levels in patients with multiple sclerosis. J Neuroophthalmol. 2001;21(1):37-8.

212. Pache M, Kaiser HJ, Akhalbedashvili N, Lienert C, Dubler B, Kappos L, et al. Extraocular blood flow and endothelin-1 plasma levels in patients with multiple sclerosis. Eur Neurol. 2003;49(3): 164-8.

213. Haufschild T, Shaw SG, Kaiser HJ, Flammer J. Transient raise of endothelin-1 plasma level and reduction of ocular blood flow in a patient with optic neuritis. Ophthalmologica. 2003;217(6):451-3.

214. Haufschild T, Prunte C, Messerli J, Flammer J. Increased endothelin-1 plasma level in young adults with retinal vascular occlusive diseases. Klin Monatsbl Augenheilkd. 2004;221(5): 357-9.

215. Todorova MG, Josifova T, Konieczka K. Endothelin-1 plasma levels in patients with both retinitis pigmentosa and Flammer syndrome. Klin Monatsbl Augenheilkd. 2015;232(4):514-8.

216. Flammer J, Kaiser H, Haufschild T. Susac syndrome: a vasospastic disorder? Eur J Ophthalmol. 2001;11(2):175-9.

217. Kida T, Flammer J, Oku H, Morishita S, Fukumoto M, Suzuki H, et al. Suppressed endothelin-1 by anti-VEGF therapy is important for patients with BRVO-related macular edema to improve their vision. EPMA J. 2016;7(1):18.

218. Oettli A, Gugleta K, Kochkorov A, Katamay R, Flammer J, Orgul S. Rigidity of retinal vessel in untreated eyes of normal tension primary open-angle glaucoma patients. J Glaucoma. 2011;20(5): 303-6.

219. Gugleta K, Kochkorov A, Katamay R, Zawinka C, Flammer J, Orgul S. On pulse-wave propagation in the ocular circulation. Invest Ophthalmol Vis Sci. 2006;47(9):4019-25.

220. Kochkorov A, Gugleta K, Zawinka C, Katamay R, Flammer J, Orgul S. Short-term retinal vessel diameter variability in relation to 
the history of cold extremities. Invest Ophthalmol Vis Sci. 2006;47(9):4026-33.

221. Flammer J, Konieczka K. Retinal venous pressure: the role of endothelin. EPMA J. 2015;6:21.

222. Killer HE, Jaggi GP, Flammer J, Miller NR, Huber AR, Mironov A. Cerebrospinal fluid dynamics between the intracranial and the subarachnoid space of the optic nerve. Is it always bidirectional? Brain. 2007;130(Pt 2):514-20.

223. Prunte C, Flammer J. Choroidal capillary and venous congestion in central serous chorioretinopathy. Am J Ophthalmol. 1996;121(1):26-34.

224. Messerli J, Flammer J. Central vein thrombosis in younger patients. Klin Monatsbl Augenheilkd. 1996;208(5):303-5.

225. Grieshaber MC, Orgul S, Schoetzau A, Flammer J. Relationship between retinal glial cell activation in glaucoma and vascular dysregulation. J Glaucoma. 2007;16(2):215-9.

226. Mienberg O, Flammer J, Ludin HP. Subclinical visual field defects in multiple sclerosis. Demonstration and quantification with automated perimetry, and comparison with visually evoked potentials. J Neurol. 1982;227(3):125-33.

227. Gugleta K, Kochkorov A, Kavroulaki D, Katamay R, Weier K, Mehling M, et al. Retinal vessels in patients with multiple sclerosis: baseline diameter and response to flicker light stimulation. Klin Monatsbl Augenheilkd. 2009;226(4):272-5.

228. Kochkorov A, Gugleta K, Kavroulaki D, Katamay R, Weier $\mathrm{K}$, Mehling $\mathrm{M}$, et al. Rigidity of retinal vessels in patients with multiple sclerosis. Klin Monatsbl Augenheilkd. 2009;226(4):276-9.

229. Gugleta K, Mehling M, Kochkorov A, Grieshaber M, Katamay R, Flammer J, et al. Pattern of macular thickness changes measured by ocular coherence tomography in patients with multiple sclerosis. Klin Monatsbl Augenheilkd. 2008;225(5):408-12.

230. Haufschild T, Kaiser HJ, Preisig T, Pruente C, Flammer J. Influence of red wine on visual function and endothelin-1 plasma level in a patient with optic neuritis. Ann Neurol. 2003;53(6):825-6.

231. Killer HE, Mironov A, Flammer J. Optic neuritis with marked distension of the optic nerve sheath due to local fluid congestion. Br J Ophthalmol. 2003;87(2):249.

232. Konieczka K, Koch S, Binggeli T, Schoetzau A, Kesselring J. Multiple sclerosis and primary vascular dysregulation (Flammer syndrome). EPMA J. 2016;7:13.

233. Teuchner B, Orgul S, Ulmer H, Haufschild T, Flammer J. Reduced thirst in patients with a vasospastic syndrome. Acta Ophthalmol Scand. 2004;82(6):738-40.

234. Konieczka K, Koch S, Schoetzau A, Todorova MG. Increased prevalence of Flammer syndrome in patients with retinitis pigmentosa. Klin Monatsbl Augenheilkd. 2016;233(4):448-52.

235. Konieczka K, Flammer AJ, Todorova M, Meyer P, Flammer J. Retinitis pigmentosa and ocular blood flow. EPMA J. 2012;3(1): 17.

236. Gugleta K, Kochkorov A, Katamay R, Husner A, Welge-Lussen A, Flammer J, et al. Olfactory function in primary open-angle glaucoma patients. Klin Monatsbl Augenheilkd. 2010;227(4): 277-9.

237. Mozaffarieh M, Hauenstein D, Schoetzau A, Konieczka K, Flammer J. Smell perception in normal tension glaucoma patients. Mol Vis. 2010;16:506-10.

238. Krauchi K, Cajochen C, Pache M, Flammer J, Wirz-Justice A. Thermoregulatory effects of melatonin in relation to sleepiness. Chronobiol Int. 2006;23(1-2):475-84.

239. Pache M, Krauchi K, Cajochen C, Wirz-Justice A, Dubler B, Flammer J, et al. Cold feet and prolonged sleep-onset latency in vasospastic syndrome. Lancet. 2001;358(9276):125-6.

240. Krauchi K, Gasio PF, Vollenweider S, Von Arb M, Dubler B, Orgul S, et al. Cold extremities and difficulties initiating sleep: evidence of co-morbidity from a random sample of a Swiss urban population. J Sleep Res. 2008;17(4):420-6.

241. Gompper B, Bromundt V, Orgul S, Flammer J, Krauchi K. Phase relationship between skin temperature and sleep-wake rhythms in women with vascular dysregulation and controls under real-life conditions. Chronobiol Int. 2010;27(9-10):1778-96.

242. Vollenweider S, Wirz-Justice A, Flammer J, Orgul S, Krauchi K. Chronobiological characterization of women with primary vasospastic syndrome: body heat loss capacity in relation to sleep initiation and phase of entrainment. Am J Phys Regul Integr Comp Phys. 2008;294(2):R630-8.

243. Krauchi K, Konieczka K, Roescheisen-Weich C, Gompper B, Hauenstein D, Schoetzau A, et al. Diurnal and menstrual cycles in body temperature are regulated differently: a 28-day ambulatory study in healthy women with thermal discomfort of cold extremities and controls. Chronobiol Int. 2014;31(1):102-13.

244. Baertschi M, Dayhaw-Barker P, Flammer J. The effect of hypoxia on intra-ocular, mean arterial, retinal venous and ocular perfusion pressures. Clin Hemorheol Microcirc. 2016;63(3):293-303.

245. Emre M, Orgul S, Haufschild T, Shaw SG, Flammer J. Increased plasma endothelin-1 levels in patients with progressive open angle glaucoma. Br J Ophthalmol. 2005;89(1):60-3.

246. Graf T, Flammer J, Prunte C, Hendrickson P. Gliosis-like retinal alterations in glaucoma patients. J Glaucoma. 1993;2(4):257-9.

247. Flammer J, Mozaffarieh M. What is the present pathogenetic concept of glaucomatous optic neuropathy? Surv Ophthalmol. 2007;52(Suppl 2):S162-73.

248. Mozaffarieh M, Grieshaber MC, Flammer J. Oxygen and blood flow: players in the pathogenesis of glaucoma. Mol Vis. 2008;14: 224-33.

249. Grieshaber MC, Moramarco F, Schoetzau A, Flammer J, Orguel S. Detection of retinal glial cell activation in glaucoma by time domain optical coherence tomography. Klin Monatsbl Augenheilkd. 2012;229(4):314-8.

250. Konieczka K, Flammer J. Glaukom [Le glaucome]. Swiss Medical Forum. 2017(17):105-12.

251. Prunte C, Flammer J. Circulatory disorders of the choroid in patients with central serious chorioretinopathy. Klin Monatsbl Augenheilkd. 1996;208(5):337-9.

252. Grieshaber MC, Staub JJ, Flammer J. The potential role of testosterone in central serous chorioretinopathy. Br J Ophthalmol. 2007;91(1):118-9.

253. Kim KE, Kim DM, Flammer J, Kim KN. Central retinal venous pressure in eyes of normal-tension glaucoma patients with optic disc hemorrhage. PLoS One. 2015;10(5):e0127920.

254. Kaiser HJ, Flammer J. Optic nerve head-related visual fields. Neuro-Ophthalmology. 1995;15:337-44.

255. Kaiser HJ, Flammer J, Messerli J. Vasospasm — a risk factor for nonarteric anterior ischemic optic neuropathy? NeuroOphthalmology. 1996;16:5-10.

256. Kaiser HJ, Flammer J, Gasser P. Ocular vasospasm in children. Neuro-Ophthalmology. 1993;13:263-7.

257. Bojinova RI, Konieczka K, Meyer P, Todorova MG. The trilateral link between anaesthesia, perioperative visual loss and Flammer syndrome. BMC Anesthesiol. 2016;16:10.

258. Bojinova RI, Konieczka K, Todorova MG. Unilateral loss of vision after spinal surgery in a patient with Flammer syndrome. Klin Monatsbl Augenheilkd. 2016;233(4):429-31.

259. Fraenkl SA, Mozaffarieh M, Flammer J. Retinal vein occlusions: the potential impact of a dysregulation of the retinal veins. EPMA J. 2010;1(2):253-61.

260. Konieczka K, Todorova MG, Chackathayil TN, Henrich PB. Cilioretinal artery occlusion in a young patient with Flammer syndrome and increased retinal venous pressure. Klin Monatsbl Augenheilkd. 2015;232(4):576-8. 
261. Terelak-Borys B, Grabska-Liberek I, Piekarniak-Wozniak A, Konieczka K. Choroidal infarction in a glaucoma patient with Flammer syndrome: a case report with a long term follow-up. BMC Ophthalmol. 2017;17(1):23.

262. Schmidt KG, Pillunat LE, Kohler K, Flammer J. Ocular pulse amplitude is reduced in patients with advanced retinitis pigmentosa. Br J Ophthalmol. 2001;85(6):678-82.

263. Turksever C, Valmaggia C, Orgul S, Schorderet DF, Flammer J, Todorova MG. Retinal vessel oxygen saturation and its correlation with structural changes in retinitis pigmentosa. Acta Ophthalmol. 2014;92(5):454-60.

264. Killer HE, Jaggi GP, Flammer J, Miller NR, Huber AR. The optic nerve: a new window into cerebrospinal fluid composition? Brain. 2006;129(Pt 4):1027-30.

265. Jaggi GP, Flammer J, Huber AR, Killer HE. Lipocalin-like prostaglandin D synthase in subretinal fluid of detached retinas in humans. Retina. 2008;28(6):858-63.

266. Jaggi GP, Miller NR, Flammer J, Weinreb RN, Remonda L, Killer HE. Optic nerve sheath diameter in normal-tension glaucoma patients. Br J Ophthalmol. 2012;96(1):53-6.

267. Killer HE, Flammer J, Miller NR. Glaucoma and cerebrospinal fluid pressure. Ophthalmology. 2008;115(12):2316-7. author reply 7

268. Killer HE, Jaggi GP, Flammer J, Miller NR. Is open-angle glaucoma caused by impaired cerebrospinal fluid circulation: around the optic nerve? Clin Exp Ophthalmol. 2008;36(4):308-11.

269. Killer HE, Miller NR, Flammer J, Meyer P, Weinreb RN, Remonda $\mathrm{L}$, et al. Cerebrospinal fluid exchange in the optic nerve in normal-tension glaucoma. Br J Ophthalmol. 2012;96(4):544-8.

270. Xin X, Fan B, Flammer J, Miller NR, Jaggi GP, Killer HE, et al. Meningothelial cells react to elevated pressure and oxidative stress. PLoS One. 2011;6(5):e20142.

271. Xin X, Fan B, Killer HE, Neutzner A, Flammer J, Meyer P. Primary cell culture of meningothelial cells - a new model to study the arachnoid in glaucomatous optic neuropathy. Graefes Arch Clin Exp Ophthalmol. 2010;248(9):1273-8.

272. Fan B, Bordigari G, Flammer J, Killer HE, Meyer P, Neutzner A. Meningothelial cells participate in immunological processes in the cerebrospinal fluid. J Neuroimmunol. 2012;244(1-2):45-50.

273. Xin X, Huber A, Meyer P, Flammer J, Neutzner A, Miller NR, et al. L-PGDS (betatrace protein) inhibits astrocyte proliferation and mitochondrial ATP production in vitro. J Mol Neurosci. 2009;39(3):366-71.

274. Killer HE, Jaggi GP, Miller NR, Flammer J, Meyer P. Does immunohistochemistry allow easy detection of lymphatics in the optic nerve sheath? J Histochem Cytochem. 2008;56(12):108792.

275. Konieczka K, Todorova MG, Bojinova RI, Binggeli T, Chackathayil TN, Flammer J. Unexpected effect of calcium channel blockers on the optic nerve compartment syndrome. Klin Monatsbl Augenheilkd. 2016;233(4):387-90.

276. Konieczka K, Flammer J, Sternbuch J, Binggeli T, Fraenkl S. Leber's hereditary optic neuropathy, normal tension glaucoma, and Flammer syndrome: long term follow-up of a patient. Klin Monatsbl Augenheilkd. 2017; doi:10.1055/s-0042-119564.

277. Satilmis M, Orgul S, Doubler B, Flammer J. Rate of progression of glaucoma correlates with retrobulbar circulation and intraocular pressure. Am J Ophthalmol. 2003;135(5):664-9.

278. Portmann N, Gugleta K, Kochkorov A, Polunina A, Flammer J, Orgul S. Choroidal blood flow response to isometric exercise in glaucoma patients and patients with ocular hypertension. Invest Ophthalmol Vis Sci. 2011;52(10):7068-73.

279. Flammer J. Glaucoma. 3rd ed. Bern: Hogrefe \& Huber; 2006.

280. Orgul S, Gass A, Flammer J. Optic disc cupping in arteritic anterior ischemic optic neuropathy. Ophthalmologica. 1994;208(6): 336-8.
281. Gugleta K, Orgul S, Flammer I, Gherghel D, Flammer J. Reliability of confocal choroidal laser Doppler flowmetry. Invest Ophthalmol Vis Sci. 2002;43(3):723-8.

282. Nau-Staudt K, Nau WM, Haefliger IO, Flammer J. Lipid peroxidation in porcine irises: dependence on pigmentation. Curr Eye Res. 2001;22(3):229-34.

283. Hemion C, Flammer J, Neutzner A. Quality control of oxidatively damaged mitochondrial proteins is mediated by $\mathrm{p} 97$ and the proteasome. Free Radic Biol Med. 2014;75:121-8.

284. Erb C, Nau-Staudt K, Flammer J, Nau W. Ascorbic acid as a free radical scavenger in porcine and bovine aqueous humour. Ophthalmic Res. 2004;36(1):38-42.

285. Moenkemann H, Flammer J, Wunderlich K, Breipohl W, Schild $\mathrm{HH}$, Golubnitschaja O. Increased DNA breaks and up-regulation of both $\mathrm{G}(1)$ and $\mathrm{G}(2)$ checkpoint genes p21(WAF1/CIP1) and 143-3 sigma in circulating leukocytes of glaucoma patients and vasospastic individuals. Amino Acids. 2005;28(2):199-205.

286. Mozaffarieh M, Schotzau A, Josifova T, Flammer J. The effect of ranibizumab versus photodynamic therapy on DNA damage in patients with exudative macular degeneration. Mol Vis. 2009;15: 1194-9.

287. Mozaffarieh M, Konieczka K, Hauenstein D, Schoetzau A, Flammer J. Half a pack of cigarettes a day more than doubles DNA breaks in circulating leukocytes. Tob Induc Dis. 2010;8:14.

288. Fang L, Neutzner A, Turtschi S, Flammer J, Mozaffarieh M. Comet assay as an indirect measure of systemic oxidative stress. J Vis Exp. 2015;99:e52763.

289. Mozaffarieh M, Schoetzau A, Sauter M, Grieshaber M, Orgul S, Golubnitschaja $\mathrm{O}$, et al. Comet assay analysis of single-stranded DNA breaks in circulating leukocytes of glaucoma patients. Mol Vis. 2008;14:1584-8.

290. Flammer J. Glaucomatous optic neuropathy: a reperfusion injury. Klin Monatsbl Augenheilkd. 2001;218(5):290-1.

291. Flammer J, Orgul S, Costa VP, Orzalesi N, Krieglstein GK, Serra LM, et al. The impact of ocular blood flow in glaucoma. Prog Retin Eye Res. 2002;21(4):359-93.

292. Konieczka K, Frankl S, Todorova MG, Henrich PB. Unstable oxygen supply and glaucoma. Klin Monatsbl Augenheilkd. 2014;231(2):121-6.

293. Mozaffarieh M, Flammer J. New insights in the pathogenesis and treatment of normal tension glaucoma. Curr Opin Pharmacol. 2013;13(1):43-9.

294. Preitner A, Orgul S, Prunte C, Flammer J. Measurement procedures in confocal choroidal laser Doppler flowmetry. Curr Eye Res. 2004;28(4):233-40.

295. Kochkorov A, Gugleta K, Katamay R, Flammer J, Orgul S. Shortterm variability of systemic blood pressure and submacular choroidal blood flow in eyes of patients with primary open-angle glaucoma. Graefes Arch Clin Exp Ophthalmol. 2010;248(6): 833-7.

296. Flammer J. Psychophysics in glaucoma. A modified concept of the disease. In: Greve EL, Leydhecker W, Raitta C (Eds.): Proceedings of the European Glaucoma Society, Second European Glaucoma Symposium, Helsinki 1984. Dr W Junk Publishers, Dordrecht. 1985:11-17.

297. Konieczka K, Fränkl S. Primäre vaskuläre dysregulation und Glaukom (primary vascular dysregulation and glaucoma). Z prakt Augenheilkd. 2013;34:207-15.

298. Mozaffarieh M, Flammer J. A novel perspective on natural therapeutic approaches in glaucoma therapy. Expert Opin Emerg Drugs. 2007;12(2):195-8.

299. Mozaffarieh M, Grieshaber MC, Orgul S, Flammer J. The potential value of natural antioxidative treatment in glaucoma. Surv Ophthalmol. 2008;53(5):479-505. 
300. Mozaffarieh M, Fraenkl S, Konieczka K, Flammer J. Targeted preventive measures and advanced approaches in personalised treatment of glaucoma neuropathy. EPMA J. 2010;1(2):229-35.

301. Gaspar AZ, Gasser P, Flammer J. The influence of magnesium on visual field and peripheral vasospasm in glaucoma. Ophthalmologica. 1995;209(1):11-3.

302. Cybulska-Heinrich A, Mozaffarieh M, Flammer J. Value of nonIOP lowering therapy for glaucoma. Klin Monatsbl Augenheilkd. 2013;230(2):114-9.

303. Grieshaber MC, Flammer J. Is the medication used to achieve the target intraocular pressure in glaucoma therapy of relevance? - an exemplary analysis on the basis of two beta-blockers. Prog Retin Eye Res. 2010;29(1):79-93.

304. Gugleta K, Orgul S, Flammer J. Experience with Cosopt, the fixed combination of timolol and dorzolamide, after switch from free combination of timolol and dorzolamide, in Swiss ophthalmologists' offices. Curr Med Res Opin. 2003;19(4):330-5.

305. Flammer J, Robert Y, Gloor B. Influence of pindolol and timolol treatment on the visual fields of glaucoma patients. J Ocul Pharmacol. 1986;2(4):305-11.

306. Flammer J, Kitazawa Y, Bonomi L, Mills B, Fsadni M, Dorigo $\mathrm{MT}$, et al. Influence of carteolol and timolol on IOP and visual fields in glaucoma: a multi-center, double-masked, prospective study. Eur J Ophthalmol. 1992;2(4):169-74.

307. Messmer C, Stumpfig D, Flammer J. Effect of betaxolol and timolol on visual fields in glaucoma patients. Klin Monatsbl Augenheilkd. 1991;198(5):330-1.

308. Messmer C, Flammer J, Stumpfig D. Influence of betaxolol and timolol on the visual fields of patients with glaucoma. Am J Ophthalmol. 1991;112(6):678-81.

309. Cybulska-Heinrich AK, Mozaffarieh M, Flammer J. Ginkgo biloba: an adjuvant therapy for progressive normal and high tension glaucoma. Mol Vis. 2012;18:390-402.

310. Flammer J. Auge und Psyche. In: H.J. Kaiser, J. Flammer (Hrsg) Kinderophthalmologie-Auge und Allgemeinerkrankungen. Hans Huber Verlag, Bern. 1999:215-24.

311. Erb C, Batra A, Lietz A, Bayer AU, Flammer J, Thiel HJ. Psychological characteristics of patients with normal-tension glaucoma. Graefes Arch Clin Exp Ophthalmol. 1999;237(9): 753-7.

312. Erb C, Thiel HJ, Flammer J. The psychology of the glaucoma patient. Curr Opin Ophthalmol. 1998;9(2):65-70.

313. von Arb M, Gompper B, Meyer AH, Stutz EZ, Orgul S, Flammer $\mathrm{J}$, et al. Relationship between gender role, anger expression, thermal discomfort and sleep onset latency in women. Biopsychosoc Med. 2009;3:11.

314. Pillunat KR, Ventzke S, Spoerl E, Furashova O, Stodtmeister R, Pillunat LE. Central retinal venous pulsation pressure in different stages of primary open-angle glaucoma. Br J Ophthalmol. 2014;98(10):1374-8.

315. Ghanem M, Gugleta K, Oettli A, Kochkorov A, Polunina A, Flammer J, et al. Analysis of retinal vein motion in glaucoma patients. Klin Monatsbl Augenheilkd. 2013;230(4):358-62.

316. Cybulska-Heinrich AK, Baertschi M, Loesche CC, Schoetzau A, Konieczka K, Josifova T, et al. Patients with diabetic retinopathy have high retinal venous pressure. EPMA J. 2015;6(1):5.

317. Mozaffarieh M, Bartschi M, Henrich PB, Schoetzau A, Flammer J. Retinal venous pressure in the non-affected eye of patients with retinal vein occlusions. Graefes Arch Clin Exp Ophthalmol. 2014;252(10):1569-71.

318. Vahedian Z, Amini H, Tehrani MH, Zarei R, Moghimi S, Mozaffarieh M, et al. Retinal venous pressure in chronic smokers. EPMA J. 2015;6(1):8.

319. Fang L, Baertschi M, Mozaffarieh M. The effect of flammersyndrome on retinal venous pressure. BMC Ophthalmol. 2014; 14:121.

320. Fang L, Turtschi S, Mozaffarieh M. The effect of nifedipine on retinal venous pressure of glaucoma patients with the Flammer-syndrome. Graefes Arch Clin Exp Ophthalmol. 2015;253(6):935-9.

321. Konieczka K. Flammer syndrom. In: Brähler E, Hoefert H-W, editors. Lexikon der Modernen Krankheiten. Medizinisch Wissenschaftliche. Berlin: Verlagsgesellschaft Berlin Deutschland; 2014.

322. Konieczka K, Gugleta K. Glaukom (4.,A). Bern: Hans Huber; 2015.

323. Konieczka K, Gugleta K. Endotheliale Dysfunktionen beim Glaukom. Ophthalmologische Nachrichten. Köln: Biermann Verlag GmbH; 2014. Deutschland 